Danmarks Geologiske Undersøgelse.

II. Række. Nr. 76.

\title{
The Geology and Bottom Deposits of Lake Tystrup Sø, Zealand.
}

\author{
By \\ Kaj Hansen.
}

With 1 map.

I Kommission hos

C. A. Reitzels Forlag

Axel Sandal

København 1950.

Pris: $5 \mathrm{Kr}$. 
Danmarks Geologiske Undersøgelse. II. Række. Nr. 76.

\title{
The Geology and Bottom Deposits of Lake Tystrup Sø, Zealand.
}

\author{
By \\ Kaj Hansen.
}

With 1 map. 


\section{CONTENTS}

I. Physiography .................. Page

a. Configuration and area of the lakes ........ 7

b. Afflux and efflux ................ 7

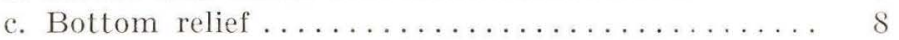

1. The northern basin of lake Tystrup So ...... 8

2. The southern basin of lake Tystrup So..... 11

3. The lake Bavelse Sø.............. 11

II. The geological development of the lakes and river Susaa 12

a. The glacio-morphological features .......... 12

b. The $35 \mathrm{~m}$ stage in lake Tystrup So ......... 16

c. The $20 \mathrm{~m}$ - $\quad$ - $\quad$ -

d. The $15 \mathrm{~m} \quad$ - $\quad$ - $\quad \ldots \ldots \ldots 23$

III. The bottom deposits in the lakes ........... 24

a. General part ...................... 24

1. The northern basin of lake Tystrup So..... 25

2. The southern basin of lake Tystrup So .... 35

3. The lake Bavelse Sø .............. 36

b. Special part................... 36

1. The calcareous mud $\ldots \ldots \ldots \ldots \ldots \ldots \ldots$

2. The iron ores $\ldots \ldots \ldots \ldots \ldots \ldots \ldots \ldots \ldots \ldots$

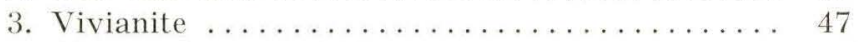

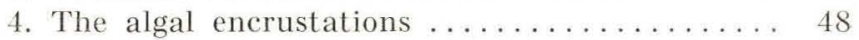

Bibliography .................... 51 


\section{Preface.}

Thile there is an abundant literature on the sediments of Swedish, German and North American lakes, the bottom deposits of Danish lakes are nearly terra incognita. In spite of the paper on Lake Marl, Lake Ores and Lake Gytje published in 1901 by Wesenbera LUND a more systematic investigation has long been needed.

In 1942 I therefore began an investigation of the sediments in Lake Tystrup Sø, Zealand (Sjælland), in co-operation with the Laboratory for Fresh Water Biology of the University of Copenhagen, and using the laboratory's annex in Suserup woods as a base. It is my aim to continue such investigations in other Danish lakes.

It is my pleasant duty to thank the Director of the Laboratory for Fresh Water Biology, Prof. KaI Berg for that friendship which he has shown me during the investigation, both in the laboratory in Hillerød, and in Suserup.

I also thank the Geological Survey of Denmark because it has agreed to include this paper in its publications, and lastly I thank the Carlsberg Fund who have subsidized the publication.

Hillerød, 10th. March 1950.

Kaj Hansen. 


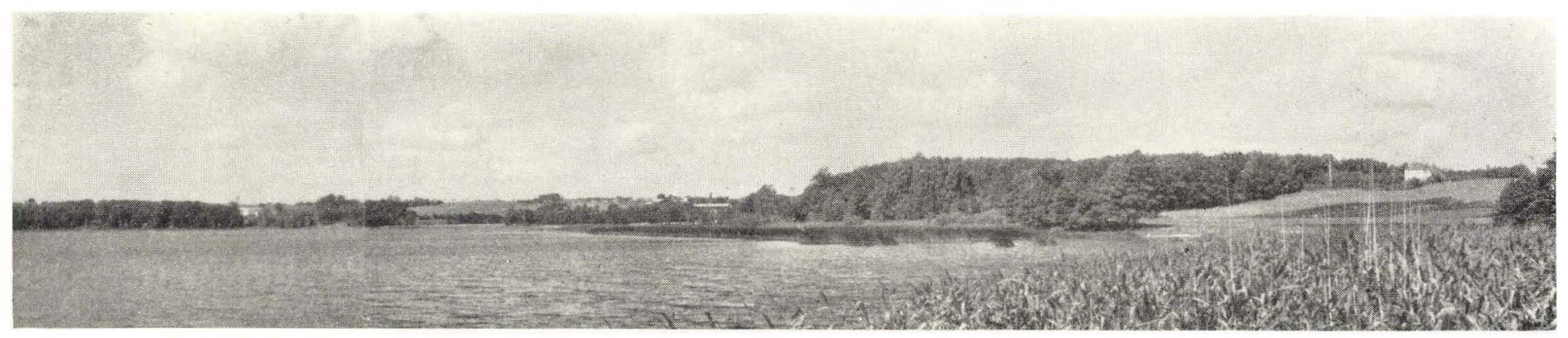

Fig. 1. The northern end of lake Tystrup Sø. To the left the Kellerod Woods, then follows the Kongskilde valley and the Frederikskilde Woods on the terrace.

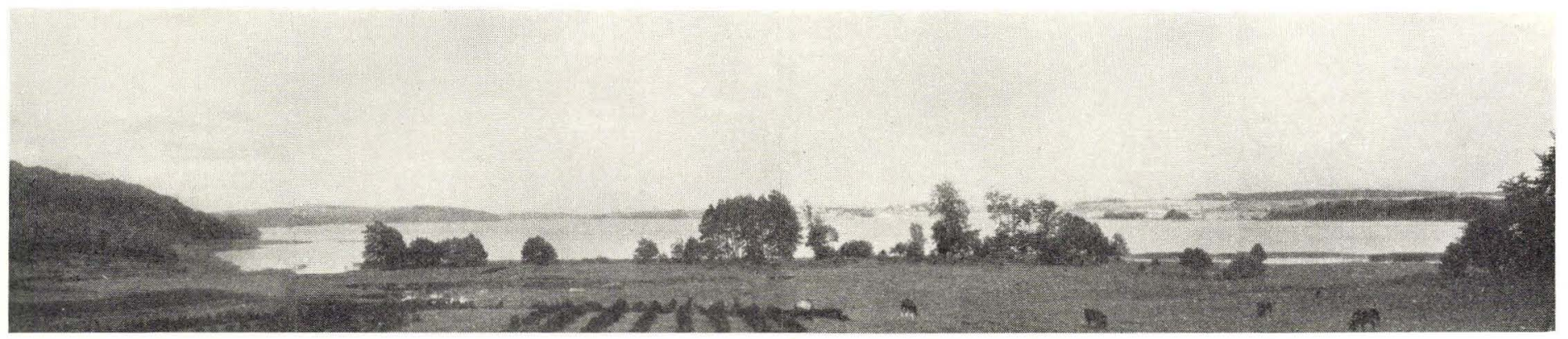

Fig. 2. Lake Tystrup So seen from the northern end. To the left the Suserup Woods and in the background the Næsbyholm Woods. The trees in the foreground are growing on the beach ridge which separates the peat filled lagoon from the lake. 


\section{Physiography.}

\section{a. Configuration and area of the lakes.}

The two lakes Tystrup Sø and Bavelse Sø make up a lake-complex in the Susaa river system in the centre of Zealand. The two lakes are situated close to each other, $6 \mathrm{~km}$ to the south of Sorø and $13.5 \mathrm{~km}$ to the north-west of Nrstved, and are only separated by a narrow isthmus, Rejnstrup Holme.

Lake Tystrup Sø is an elongated sub-glacial valley lake with two basins separated by a threshold with a water-depth of $1-3 \mathrm{~m}$. The longitudinal direction in the northern basin is NW-SE and in the southern basin E-W.

The lake is $7 \mathrm{~km}$ long from Kongskilde to the southern shore by Rejnstrup and the area is $6.62 \mathrm{sq} . \mathrm{km}$.

The northern basin is $4.5 \mathrm{~km}$ long from Frederikskilde on the northern shore to the bend by Hørhave, and from here to the threshold in the narrow southern end there is $0 . \mathrm{km}$. The southern basin is $2 \mathrm{~km}$ long.

The width of the lakes varies very greatly from one place to another. The northern basin has its greatest width in the cross-section from the mouth of river Susaa to the village Tystrup, and is here $1240 \mathrm{~m}$ wide. The meandering narrow southern end is only $400-500 \mathrm{~m}$ wide, and the southern basin is $1040 \mathrm{~m}$ wide.

The connection between lake Tystrup Sø and lake Bavelse Sø is through the $150 \mathrm{~m}$ long and $60 \mathrm{~m}$ wide channel between the northern shore of the lakes and the isthmus Rejnstrup Holme. The open part of the channel meanders through dense reed swamps and is only 15-18 $m$ wide.

Lake Bavelse Sø has a water area of $0.93 \mathrm{sq} . \mathrm{km}$, is $1900 \mathrm{~m}$ long and $900 \mathrm{~m}$ wide. The surface of the lakes is $7 \mathrm{~m}$ above sea level.

The total area of the lakes is 755 ha.

\section{b. Afflux and efflux.}

The main afflux to the lakes is the river Susaa, which flows into the northern basin of lake Tystrup Sø in the middle of its eastern side 
and leaves lake Bavelse Sø from its south-eastern corner. The "Torpe Kanal" enters at the north-eastern corner of lake Bavelse Sø and takes a part of the water from the upper course of the river Susaa direct to lake Bavelse Sø (BERG 1943). In the north-western corner of the northern basin of lake Tystrup Sø two smaller streams run into the lake throughout the year, and several other streams which dry up in summer and are of no importance.

On the stretch of $100 \mathrm{~m}$ at the north-western end of lake Tystrup Sø several springs send their water into the lake, and in Suserup Woods there are other springs whose water runs into the lake.

\section{c. Bottom Relief.}

In the year 1894 ARThur Feddersen published a map of the TystrupBavelse lakes showing the main features of the bottom relief on the scale of 1:30000. Investigations in the lakes in recent years have shown that some corrections are necessary. In connection with the bottom investigations the author has made several sounding traverses, a reading being taken for every twenty five oar strokes on a traverse between two points on the shores. This method is not very accurate, for when the wind is blowing strongly it is difficult to hold course, and as the soundings were taken in the years 1945-1947, some in the spring, some in the summer and others in the autumn, one cannot be sure that the water level in the lakes was exactly the same at all times. There is control where the different sounding traverses cross one another, and this shows a rather close correspondence between the depths on the different traverses. The map (appendix) is, so far as the northern basin of lake Tystrup Sø is concerned, constructed as a combination of the old map of Feddersen and the new soundings. In the southern basin and in lake Bavelse Sø the author has only made a few traverses and the depth-curves are here drawn entirely on the basis of Feddersen's map.

\section{The northern basin of lake Tystrup Sø.}

From the maps fig. 14 and appendix and the cross-sections fig. 3 it is seen that the lake as a whole is a valley depression with the main direction NW-SE, and a rather flat floor, at a depth of c. $18 \mathrm{~m}$ below lake level. The greatest depth, $21 \mathrm{~m}$, is found in the narrow southern part to the north-east of Vinstrup.

The actual valley is situated for the most part near the south-western shore, only in the cross-sections Lindesøgaard-Sarauwsminde and Tystrup- 


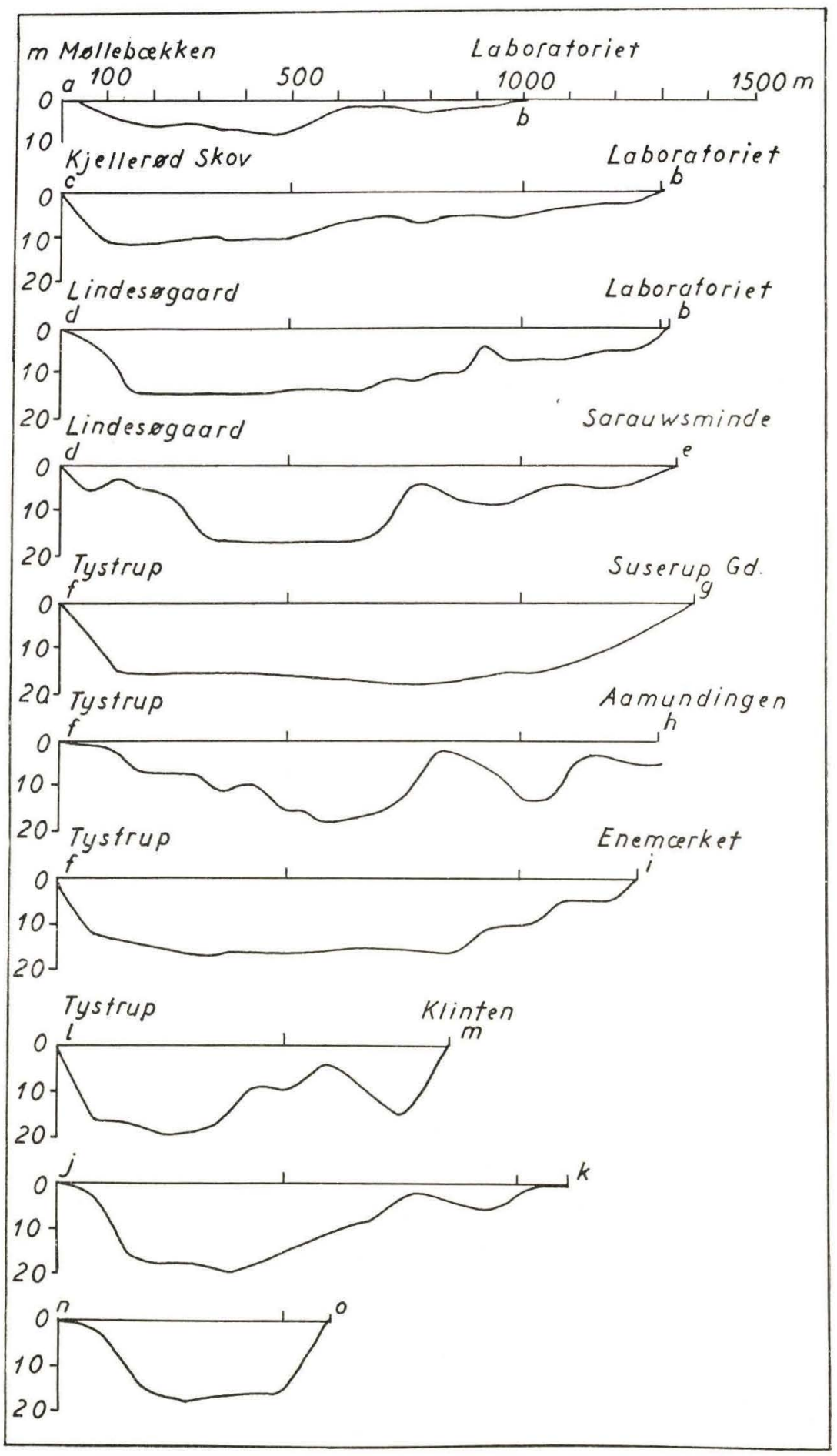

Fig. 3. Cross-sections of the northern basin of lake Tystrup So. 
Aamundingen (river mouth) is it situated at a greater distance from this shore. In all the other cross-sections the lake bottom slopes steeply from the south-western shore to a depth of $10 \mathrm{~m}$ in the north-western corner, and more to the south to $15 \mathrm{~m}$. The gradient is generally $1: 9$, or 11 per cent.

In the cross-section Lindesøgaard-Sarauwsminde, the lake bottom slopes first to a depth of $6 \mathrm{~m}$ at a distance of $60 \mathrm{~m}$ from the shore, but then rises to a submerged bank, with the top $130 \mathrm{~m}$ from the shore and a water depth of $3 \mathrm{~m}$. From here the bottom at first slopes gently, later more steeply to the floor of the valley with a depth of $16 \mathrm{~m}$ at distance of $350 \mathrm{~m}$ from the shore.

In the cross-section Tystrup-Aamundingen the lake bottom slopes with several terraces to a depth of $18 \mathrm{~m}$ at a distance of $590 \mathrm{~m}$ from the shore, the terraces being situated at depths of 7 and $11 \mathrm{~m}$.

Along the north-eastern side of the lake the bottom relief is considerably more irregular. In the cross-section Tystrup-Suserup Gaard the lake floor slopes rather steeply to a depth of $11 \mathrm{~m}$ at a distance of 120 $m$ from the shore. The gradient is $1: 11$, or 9 per cent. From the eastern border of Suserup Woods a broad shoal extends into the northern part of the lake; it has its greatest width opposite the point to the west of Sarauwsminde. The water depth on the shoal is everywhere less than $7 \mathrm{~m}$.

From the outermost point of the shoal, the bottom slopes steeply to the floor of the valley with a gradient of $1: 17$, or 6 per cent. Both east and west of this point, the slope is more gentle and terraced.

In the cross-section Lindesøgaard-Laboratoriet a terrace is situated at a depth of $10 \mathrm{~m}$ and the floor of the valley is here at a depth of $15 \mathrm{~m}$. In a cross-section from Tystrup to Sarauwsminde the eastern part of the lake bottom slopes with terraces to the floor of the valley with a depth of $18 \mathrm{~m}$ at a distance of $740 \mathrm{~m}$ from the shore. The terraces are at depths of $8-10 \mathrm{~m}$ corresponding to the terraces in the cross-section Lindesøgaard-Laboratoriet, and at depths of 13-15 $\mathrm{m}$ corresponding to the valley floor in the same cross-section. A terrace corresponding to the shoal is to be found at a depth of $5 \mathrm{~m}$.

As is to be seen from the map (appendix) and the top four crosssections in fig. 3 the surface of the shoal is rather uneven. On the outermost part near the slope to the valley floor there is a long, slender ridge with a meandering course. The highest point of this ridge is on the cross-section Lindesøgaard-Sarauwsminde, and is covered by only $1 \mathrm{~m}$ of water.

In the cross-section Tystrup-Aamundingen the water depth in the river mouth is $3 \mathrm{~m}$, after which the lake bottom slopes steeply to $13 \mathrm{~m}$ with a gradient of $1: 5$, or 20 per cent. Farther out a bank (Aagab- 
grunden) rises to a depth of only $2 \mathrm{~m}, 350 \mathrm{~m}$ from the shore. The outer side of this bank slopes down to $16 \mathrm{~m}$ with a gradient of $1: 8$, or 12.5 per cent, and then to $18 \mathrm{~m}$ with a gradient of $1: 30$, or 3.3 per cent.

Also opposite Enemærket the lake bottom slopes with terraces to a depth of $16 \mathrm{~m}$, which in the cross-section Tystrup-Enemærket is reached at a distance of $440 \mathrm{~m}$ from the shore. There are two terraces at depths of 5 and $10 \mathrm{~m}$.

Flodevig is a shallow bay with a depth of less than $5 \mathrm{~m}$. From the southern end of Klinten (The Cliff) a submerged ridge runs $200 \mathrm{~m}$ to the NW at a depth of not more than $2 \mathrm{~m}$.

To the west of Klinten the lake bottom slopes steeply to $15 \mathrm{~m}$, the gradient is $1: 10$, or 10 per cent. Farther out, $260 \mathrm{~m}$ from the shore, a bank rises to a depth of $4 \mathrm{~m}$. On the western side of this bank there is a terrace at a depth of $8-10 \mathrm{~m}$, the lake bottom slopes to a depth of $20 \mathrm{~m}$ with a gradient of $1: 14$, or 7.7 per cent. (Cross-sections $\mathrm{j}-\mathrm{k}$ and $\mathrm{l}-\mathrm{m})$.

The narrow southern end of the basin is most likely a meandering river valley with very steeply sloping sides. The depth is uniformly $18 \mathrm{~m}$ until the bend by Hørhave At the southern end there is a threshold with depths of not more than $1-3 \mathrm{~m}$. This threshold is narrowest in the south-eastern corner and broadens from the middle of the course northward to the proximity of Hørhave. Three small islets overgrown with Phragmites are situated on this broad shallow.

\section{The southern basin of lake Tystrup Sø.}

This has a much more simple configuration than the northern basin. The bottom slopes with an average gradient of 1:14, or 7.1 per cent down to the broad floor at a depth of $20 \mathrm{~m}$. As is to be seen from the map the actual valley floor has also here a gently meandering course. In the middle of the lake it is situated closer to the northern shore, whereas at both ends it is closer to the southern shore. Towards Rejnstrup Holme the slope is quite gentle with a gradient of $1: 11$, or 9 per cent.

\section{The lake Bavelse Sø.}

Lake Bavelse Sø is a regular shallow basin, with depths not exceeding $8 \mathrm{~m}$. The floor is quite flat and the slopes have a gradient of 1:14 or 7 per cent, nearly the same as in the southern basin of lake Tystrup Sø. In lake Bavelse Sø also, the slope towards Rejnstrup Holme is gentle. The narrow eastern end of the lake forms a $300 \mathrm{~m}$ broad shoal with a water depth of not more than $2 \mathrm{~m}$. From here the lake narrows and is funnel-shaped leading to the lower course of the river Susaa. 


\section{The Geological Development of the Lakes and River Susaa.}

The Tystrup-Bavelse lake system and other lake basins of the same type, for example lake Haraldsted Sø, lake Gyrstinge Sø and several of the lakes in the Gudenaa river system in Jutland are probably formed in the same way by sub-glacial erosion. They are part of a sub-glacial river system (fig. 4) originating in the deep channel, Hølen, between the islands Nyord and Zealand, which runs in a north-westerly direction into the fiord between Jungshoved and Tjørnehoved and further by way of the valleys of the Tubæk and Risby Aa to Bøgesø. From here the system has its continuation in the Mogenstrup Esker, the lower part of the Susaa valley and the lakes Tystrup Sø-Bavelse Sø. (KaJ Hansen 1945 a, Mikkelsen 1949).

There is no doubt that the northern basin of lake Tystrup Sø is a sub-glacial valley, but in the southern basin and lake Bavelse Sø tunnelvalley character is less pronounced, and it has probably been disturbed by the glacier advancing to the terminal moraine in the Næsbyholm Woou's (S.A.Andersen 1924). V. Milthers states that the sub-glacial river has run through the complex of depressions and river valleys $3 \mathrm{~km}$ east of the present day lower river Susaa from Gangensbro, by Køberup and Ravnstrup to Torpe Kanal, and from here to the west by way of Nødholm and Regerup to the eastern end of lake Bavelse Sø. (V. Milthers 1948).

The way in which the inland ice melted away, and the development of the landscape has been much discussed, and the various views differ rather considerably. (S. A. Andersen 1924 and 1931, K. Milithers. 1942, V. Milthers 1908, 1916, 1948).

\section{a. The glacio-morphological features.}

In order the better to understand the development of the lakes it will be necessary to study the development and landscape forms in the whole river Susaa district, as shown in fig. 5 .

In the eastern part the landscape consists of a multitude of drumlins, ridges of moraine, whose longitudinal axes indicate the direction of movement of the ice. It is clearly seen that this has been E-W, and the drumlin landscape has therefore been formed by a glacier coming. from the east. (MiLthers 1948). 


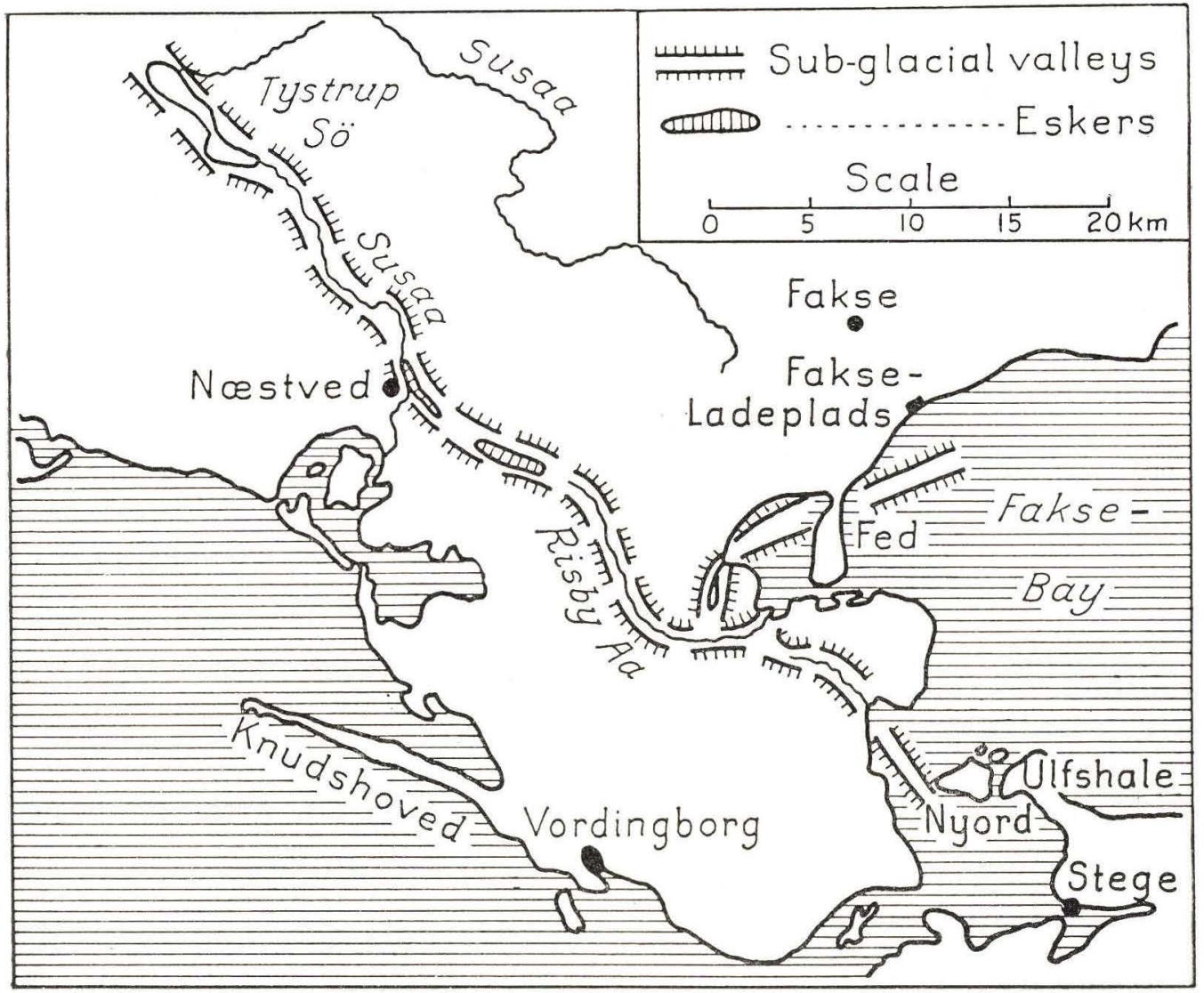

Fig. 4. The sub-glacial valleys in southern Zealand.

To the north and east of the lower Susaa valley a range of high hills runs from the Næsbyholm Woods in a curve to the north and east of Glumsø, continuing southwards to Herlufmagle and Stenskoven. This range must be understood as the lateral and terminal moraine of a glacier tongue moving through Storebælt (fig. 6).

As is to be seen in fig. 5 some of the eastern drumlins extend under the lateral moraines of the Storebælt glacier. This means that the eastern ice originally extended much further to the west and covered southern Zealand and a part of Funen (older dalabaltic glacier, K. Milthers 1942), and that the expansion of the Storebælt glacier did not take place before the eastern glacier had begun to stagnate (WENNBERG 1943 stage D-E).

Between the brook Tyvelse Møllebæk and the upper course of river Susaa (up-stream of the mouth of the river Ringsted Aa) is situated another long hill. This ridge was also interpreted as a lateral moraine (S. A. Andersen 1931) or drumlin (V. Milthers 1948) belonging to the 

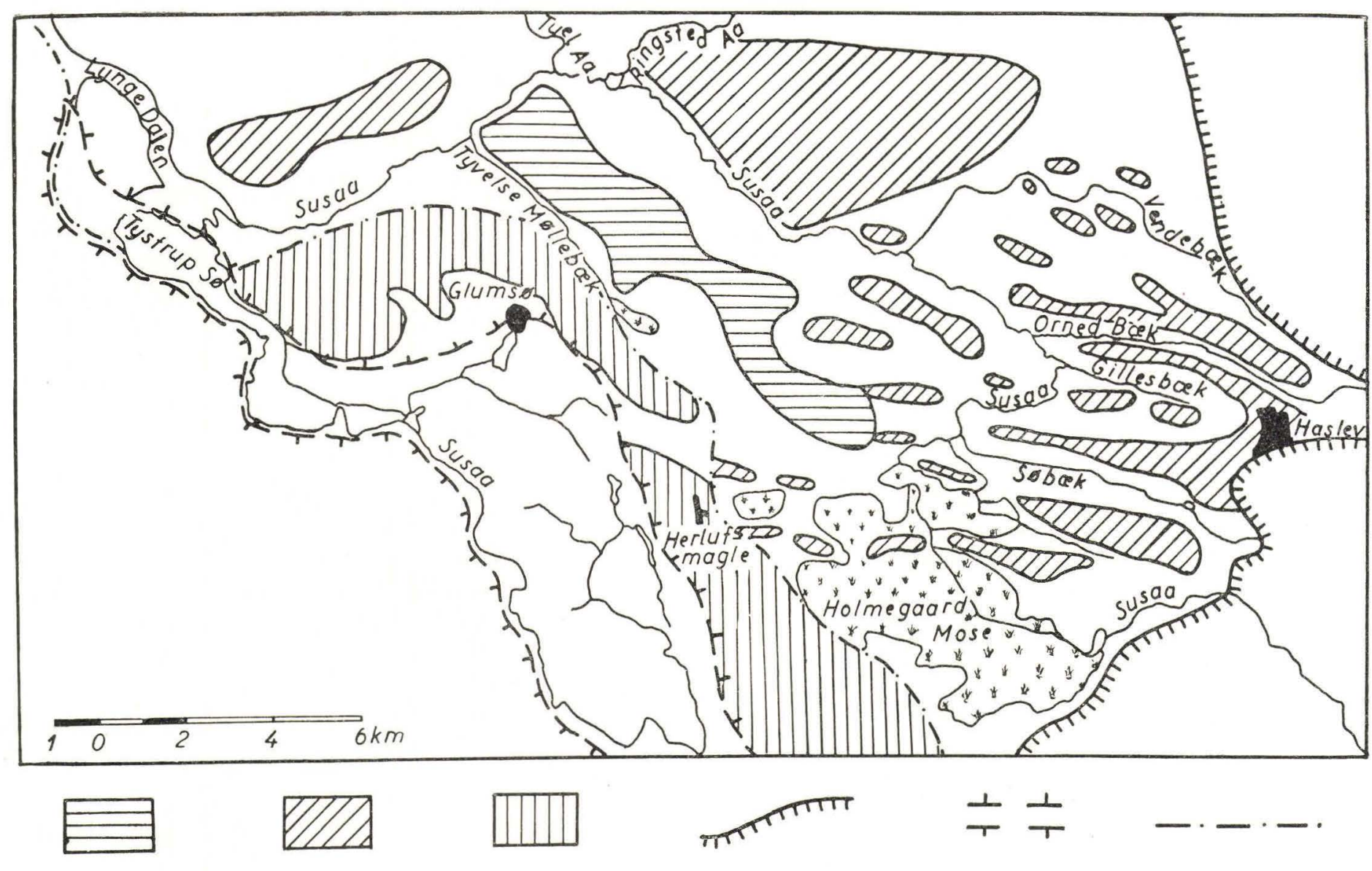

$\stackrel{+}{+}$

Kames

Drumlins deposited by the eastern glacier

Lateral moraine of the Storebraltglacier
The middle Zealand glacier-front
Sub-glacial valley
The boundary border between the eastern glacier and the Storebrlt-glacier

Fig. 5. The landseape forms in the river Susaa district. 


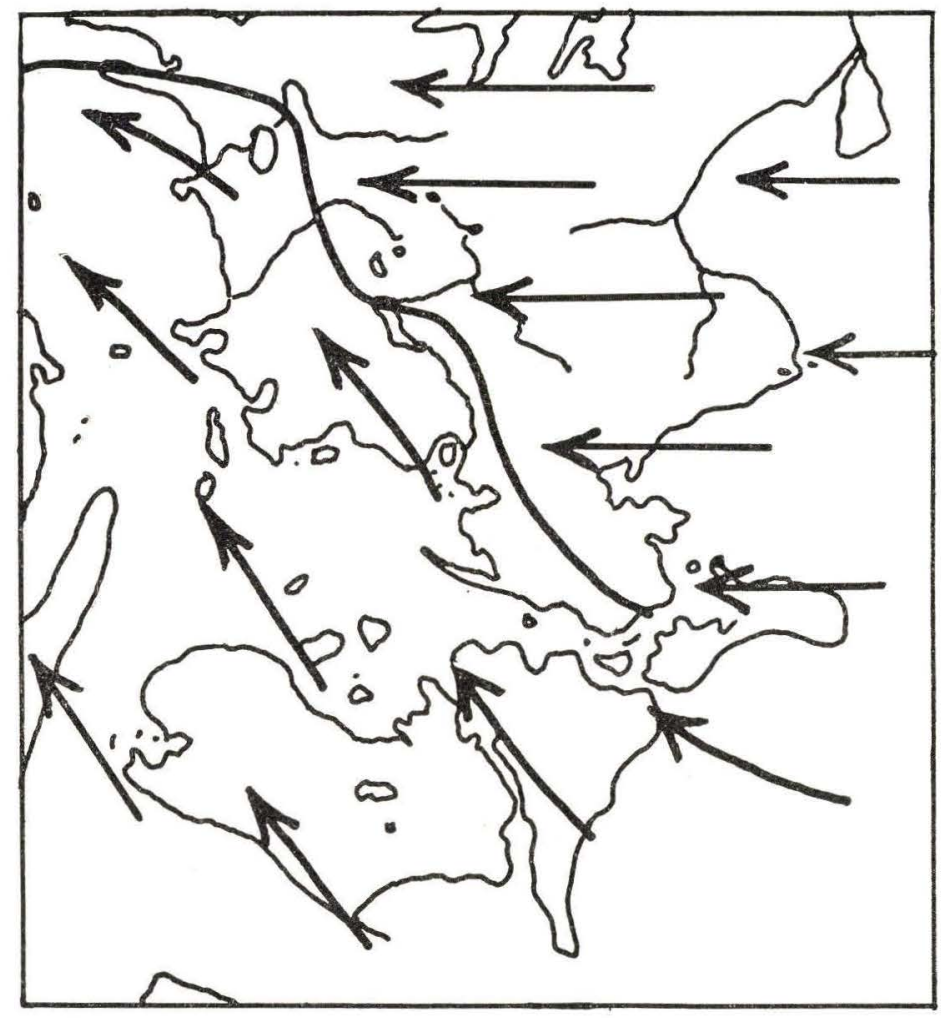

Fig. 6. Ice streams crossing Zealand during the last glaciation.

Storebælt-glacier, but by Tyvelse and Sandby there are brickworks in whose pits is to be seen clay covered by sand. The ridge is, therefore, a plateau hill (a sort of kame), representing the former bottom of a glacier dammed lake. As some of the drumlins from the eastern glacier continue beneath the ridge, it cannot have been formed before the eastern glacier had begun to stagnate.

In the western and south-western part of the drumlin landscape the basins between the hills are filled with extensive peat-bogs, and beneath the peat there is late-glacial clay. These basins must, therefore. have been a complex of lakes during a part of late-glacial time. To the east and south the river Susaa is bordered by a somewhat differently developed landscape which is a part of the middle Zealandian stagnation border (Giesegaardlinien). This is the youngest element in the landscape (WENNBERG 1943, stage F.).

The oldest elements of the landscape formed during the melting of the inland ice are the plateau hills and Eskildstrup Esker near the north-western end of lake Tystrup Sø.

The glacial lake may originally have been a depression in the surface of the dead glacier which has been gradually filled up, at first with 
clay and later with sand. The outlet from this glacial lake may have run on the surface of the ice, probably to the north or north-west.

The Eskildstrup Esker is interpreted by S.A. Andersen at first as a terminal moraine (1924 p. 16), but in a later paper (1931 p. 124) it is referred to as an esker. It is no more to be seen. A younger system of eskers is perhaps represented by the banks in Tystrup lake. The bank to the west of Klinten, Aagabgrunden and the long slender meandering ridge on the shoal by Suserup Woods are all situated in such a way that they appear to be isolated hills in an esker chain. The first two of these banks are built up of gravel.

Whether the esker-like hill in Kjellerød Woods is an esker is perhaps doubtful. It could possibly be a river-eroded residual ridge between two streams coming from the slopes to the north of Lindesøgaard.

\section{b. The $35 \mathrm{~m}$. stage lake Tystrup Sø.}

The outlet of the sub-glacial river system was originally to the north through the Kongskilde-Topshøj valley (fig. 7) where the windgap now is $46 \mathrm{~m}$ above sea level. Later the outlet was by way of the Lynge valley in which the windgap now is $42 \mathrm{~m}$ above sea level. A curious feature of the landscape round the northern end of lake Tystrup Sø is the high escarpment, which runs from the northern side of the Susaa valley to the north along the western border of Broby Vesterskov, continuing northward to Suserup, along Rytterbjerg and again swinging to the north-west by Bjerringhuse into the Kongskilde valley. The base of this escarpment is $32 \mathrm{~m}$ above sea level.

The idea that the escarpment represents one side of a late-glacial extra-marginal river valley, the glacier having formed the other, and the water having flowed from Tystrup lake to the east through the middle course of river Susaa into Tuel Aa and through that stream northward is very attractive (fig. 8).

Such one-sided valleys are known from many other places in Denmark, for example near Arnager in the south of Bornholm.

The Tuel Aa valley is a hanging side-valley to the Susaa valley and is $32 \mathrm{~m}$ above sea level (fig. 9), this corresponds very well with the $35 \mathrm{~m}$ stage in lake Tystrup Sø suggested by S. A. Andensen (1931). The suggestion also agrees with a modified form of the point of view of V. Milthers (1916). The glacier border along the south side of the valley may have crossed lake Tystrup Sø from Klinten in the Næsbyholm Woods to a little south of Hulegaard. The meltwater may have left the glacier near the southern end of Hulebanke. In the gravel pits here, which extend to $35 \mathrm{~m}$ above sea level, it is to be seen that the uppermost $5 \mathrm{~m}$ of the hill consist of alternating layers of sand 


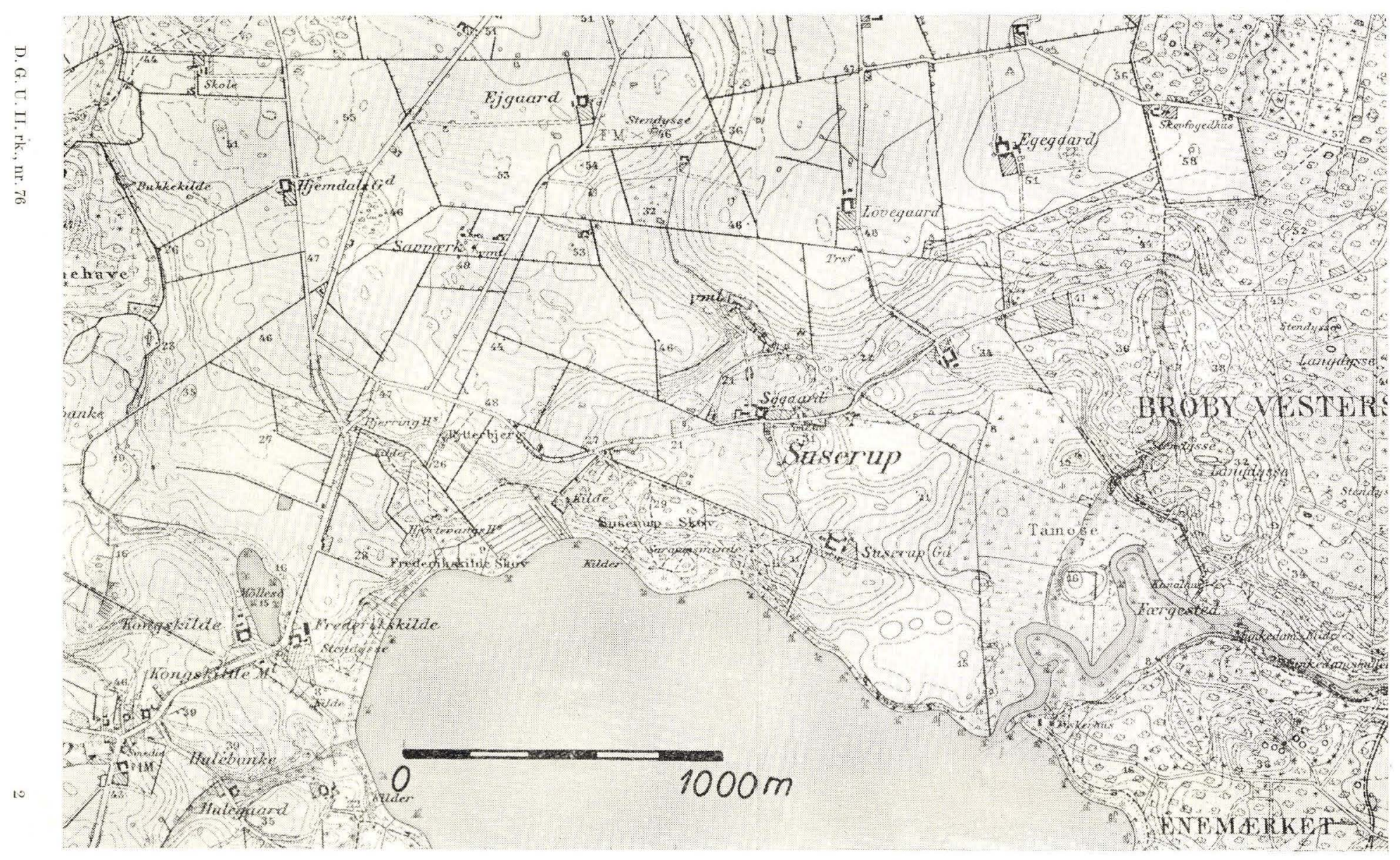

Fig. 7. The landscape to the north of lake Tystrup So. To the left the Kongskilde-Topshoj valley. To the north of Suserup the Lynge valley. 


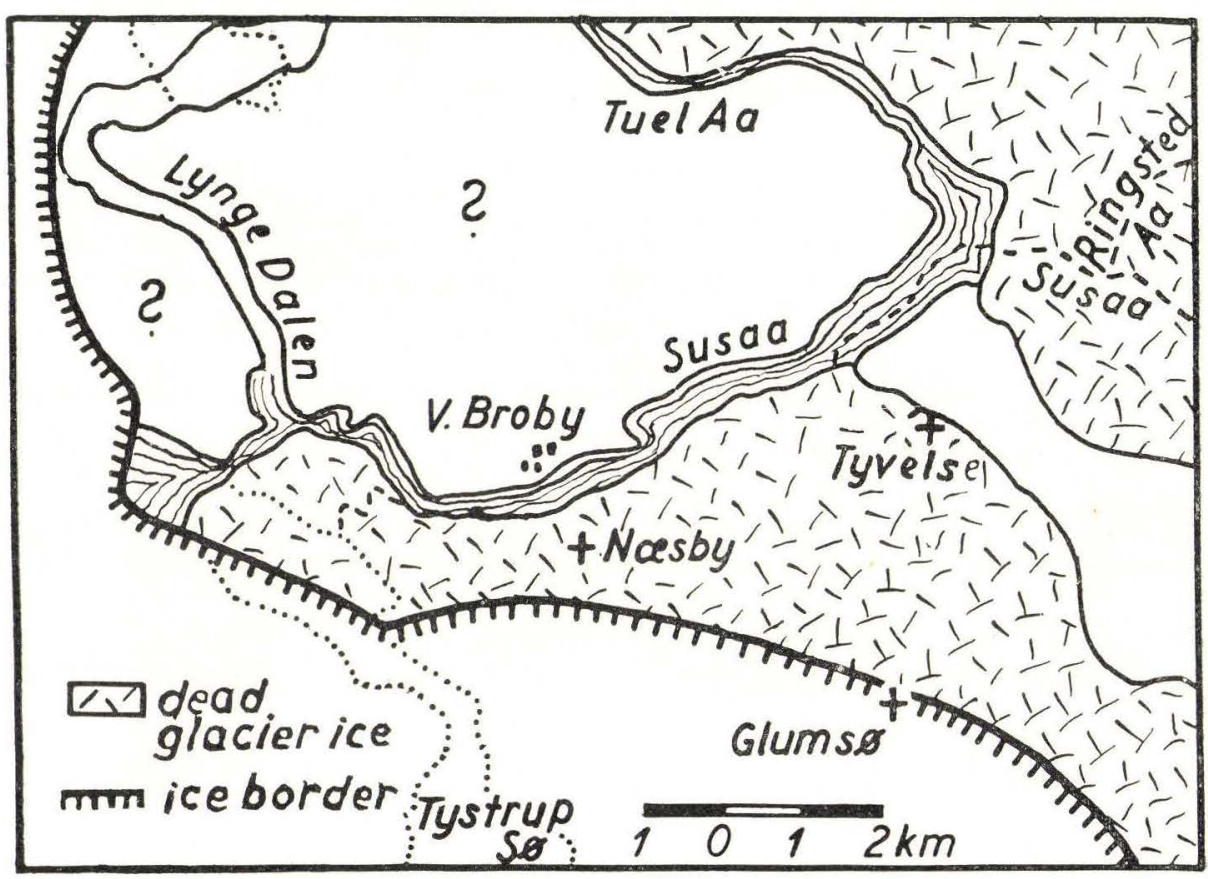

Fig. 8. The $35 \mathrm{~m}$ stage in river Susaa.

and gravel, probably deposited close to the river mouth in the glacier front. In front of the escarpment in the Kongskilde valley there is a broad terrace whose outer border slopes steeply towards lake Tystrup Sø from a height of $17 \mathrm{~m}$ above sea level (figs. 7, 10, 11 and 12). More to the east the landscape between Suserup and the lake is irregular, with several small hills and kettle holes indicating that the area between the escarpment and the ice must have been covered by dead ice.

At this stage the plateau hill between the brook Tyvelse Møllebæk and the upper course of the river Susaa may have risen above the dead ice, since the stone-free clay in the brickwork pits by Sandagergaard and Sandby reaches a height of $50 \mathrm{~m}$ above sea level. At the same time the highest part of the country to the north of Susaa may have been free from ice cover. There is reason to belive that the melting of the ice has taken place by the ice cover gradually having become thinner and more flat, rather than by the retreat of a steep ice front. The floor of the middle Susaa valley must also have been covered by dead ice to a height of $30-35 \mathrm{~m}$ above sea level and the river has flowed on a bed of ice

At this stage or a little later the water from lake Haraldsted Sø presumably had its outlet to river Susaa through the river Ringsted Aa. 


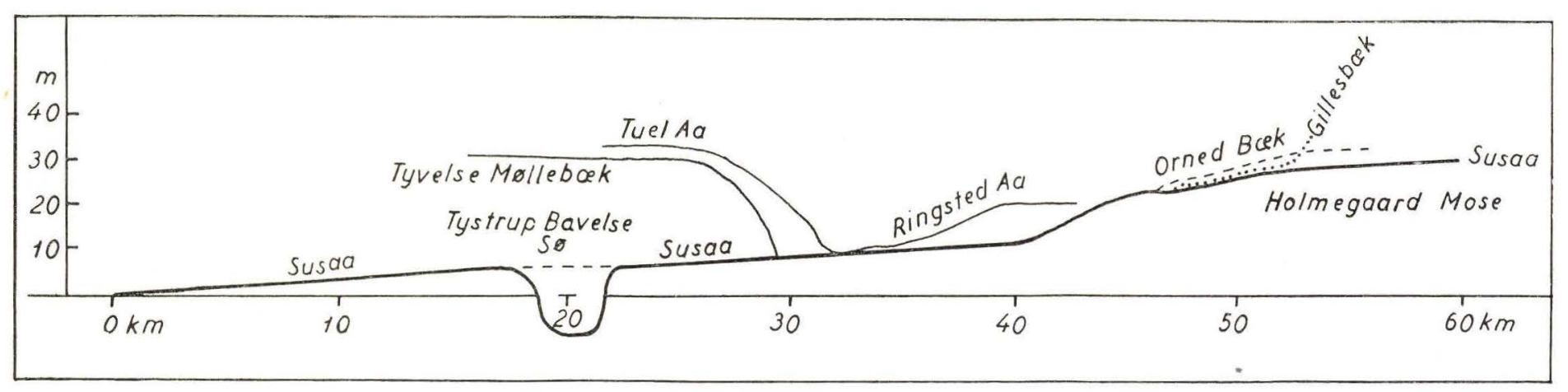

Fig. 9. Graded profile of river Susaa.

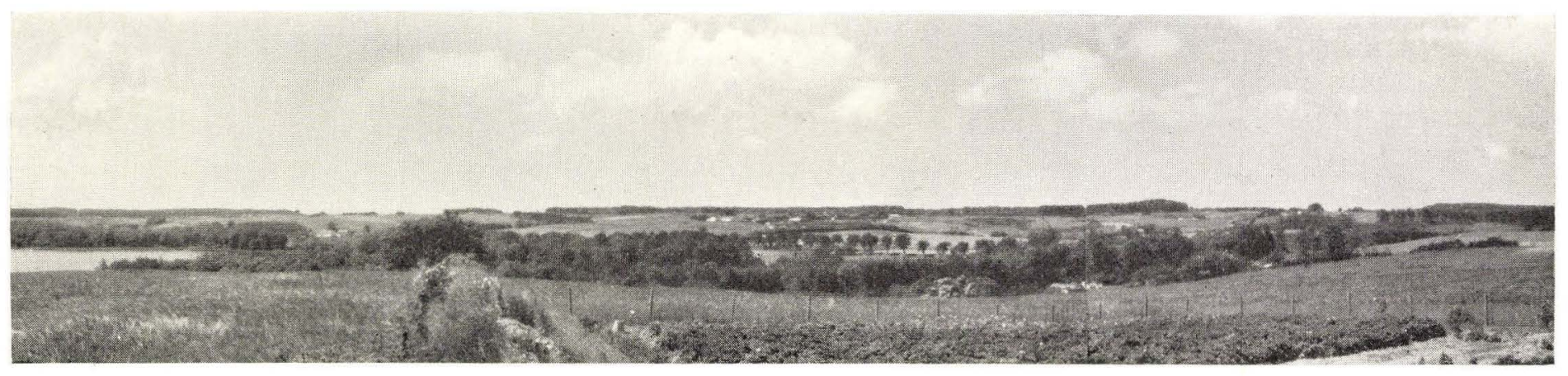

Fig. 10. View to the west from the western border of Frederikskilde Woods. To the left lake Tystrup So and the Kongskilde valley. In the foreground the terrace, In the background to the right the Topshoj Woods. 


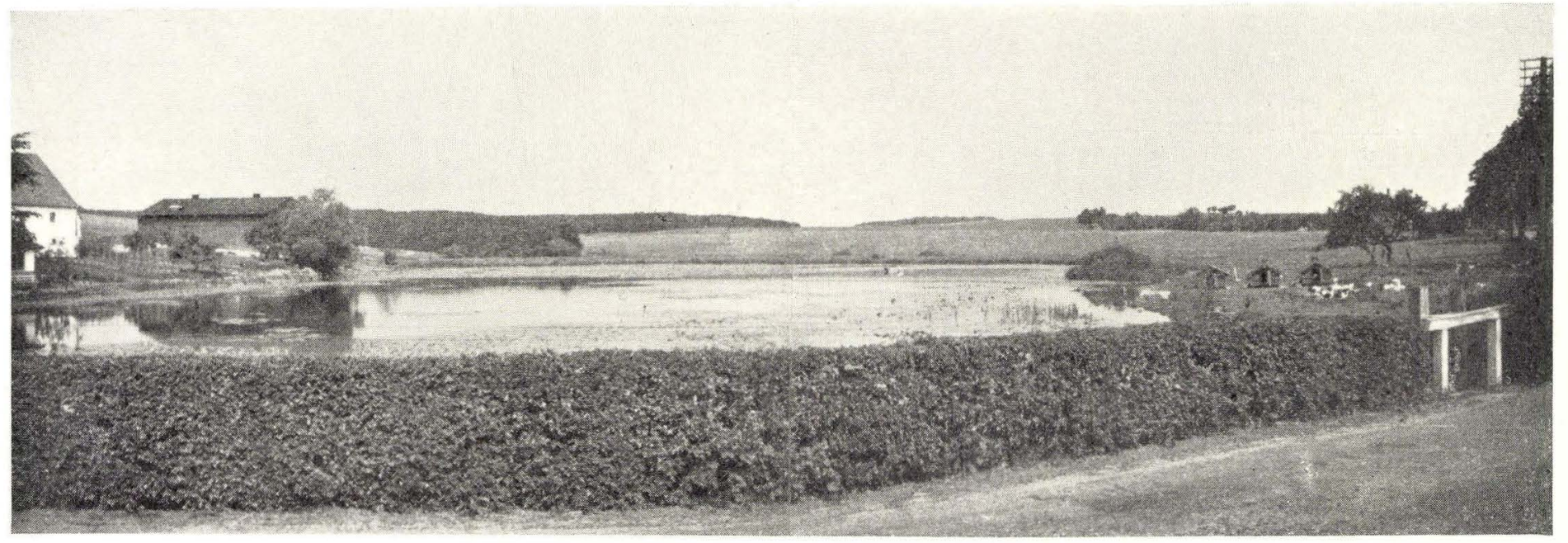

Fig. 11. The terrace seen from the bottom of the Kongskilde valley. In the foreground the Kongskilde mill pond. In the background the Topshoj Woods. 


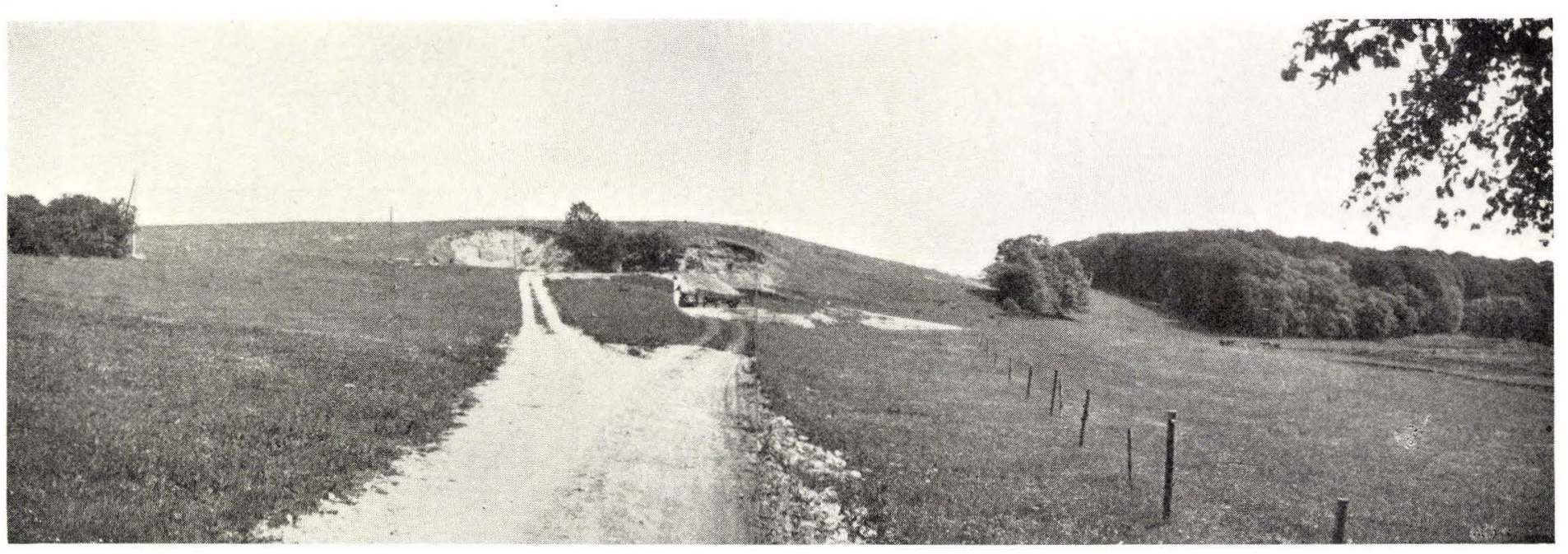

Fig. 12. The slope and the terrace near Rytterbjerg. To the right the Suserup Woods. 


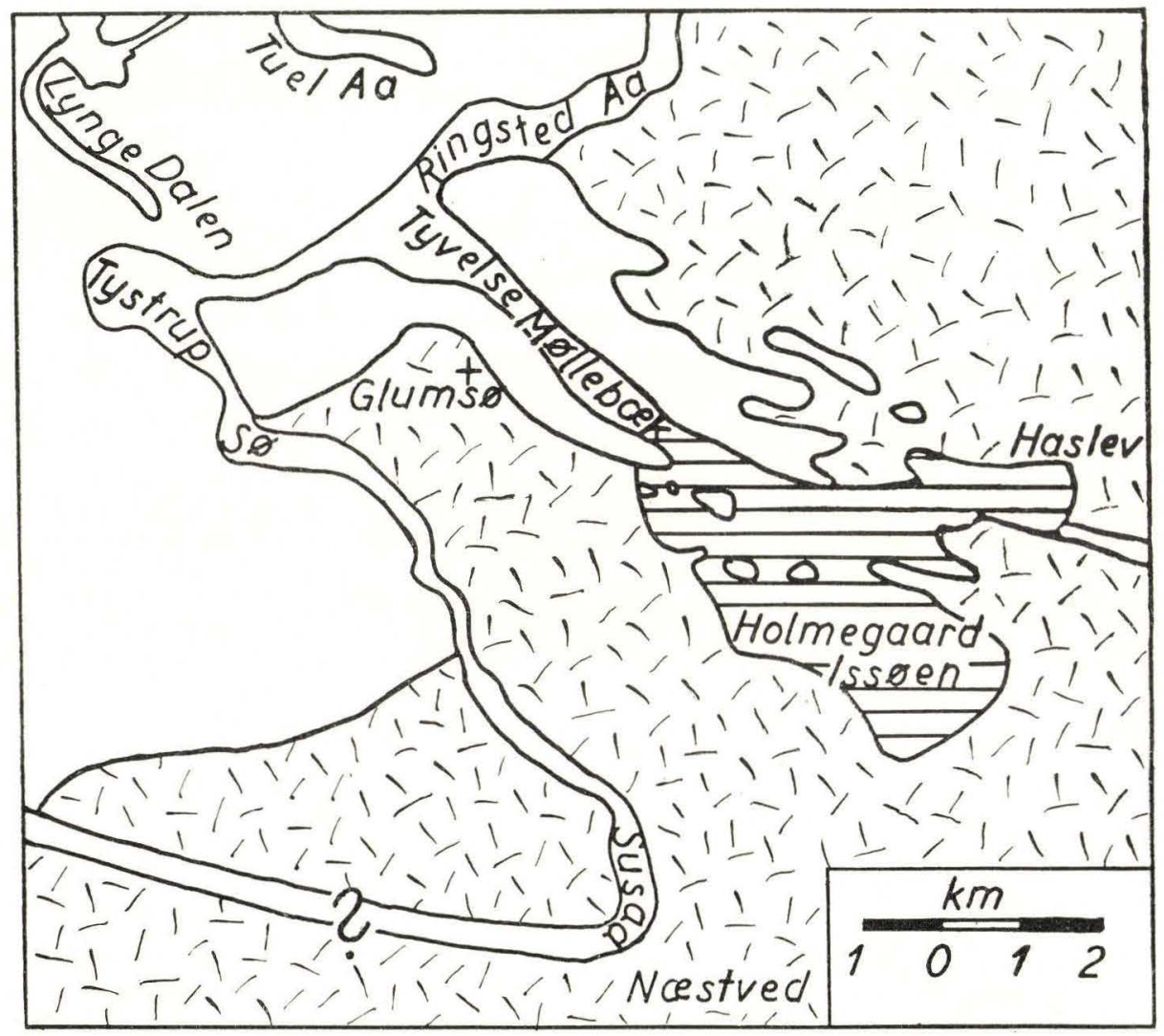

Fig. 13. The $20 \mathrm{~m}$ stage of river Susaa.

\section{c. The $20 \mathrm{~m}$ stage in lake Tystrup Sø.}

The next assignable stage in the development of lake Tystrup Sø is the $20 \mathrm{~m}$ stage. (S. A. Andersen 1931). Slight traces of it are met with here and there along the borders of the lake and along the lower course of river Susaa as far as Herlufsholm, where they suddenly disappear.

The meltwater stream from the south may already have stopped by the time the $20 \mathrm{~m}$ stage was formed. The old sub-glacial channel had collapsed or had been filled with ice, and lake Tystrup Sø had its outlet to the south through the lower course of the river Susaa; at this stage there was no real lake. The present lake depression was probably filled with ice and on the surface of this a river had a strongly meandering course. Here and there it ran on the ice-free land surrounding the valley and deposited small sand terraces (kame terraces) $20 \mathrm{~m}$ above sea level. The sea 'Smaalandshavet' to the south of Zealand was at this time still covered with ice, and the water from river Susaa cut 
its way through the ice covering the lower lying parts of southern Zealand, passing Næstved to the north and west and running into the valleys of the rivers Saltø Aa and Bjerre Aa, then to the river Tudeaa by Trelleborg and farther on to the Storebælt north of Korsør (fig. 13).

The $20 \mathrm{~m}$ stage in Lake Tystrup Sø corresponds to the main terrace between the mouth of the brook Tyvelse Møllebæk and Hjelmsølille in the middle course of the river Susaa. The valley of Tyvelse Møllebæk hangs at this level (fig. 9), and the main terraces of the river Susaa have a steeper slope between Tovetit near Næsby and the mouth of Tyvelse Møllebæk than both upstream and downstream of this section. This irregularity in the profile of the main terrace probably means that a new cycle of erosion started after the $20 \mathrm{~m}$ stage, and that this cycle was interrupted, as the base level changed to $15 \mathrm{~m}$ when the water found an outlet in the neighbourhood of Næstved. The brook Tyvelse Møllebæk was probably the outlet from the large peat bogs $\mathrm{Hol}^{-}$ megaard Mose, Porsmose, Herlufmagle Mose and Kroglyng during the $20 \mathrm{~m}$ stage, but the depression surrounding the upper course of the river Susaa to the north of a line from Tybjerglille-Testrup to Haslev was still ice covered. (figs. 5 and 13).

\section{d. The $15 \mathrm{~m}$ stage in lake Tystrup Sø.}

This stage can be followed along the whole south-western shore of the lakes as clay and sand deposits, or terraces corresponding to the main terrace in the lower course of river Susaa as far as its mouth, where the terrace apparently ends as a sand fan in the neighbourhood of Aaderup (S. A. Andersen 1931). Along the upper Susaa this stage can be followed as far as to the north of Testrup after which it continues along the brook Gillesbæk, which is to be regarded as the late glacial upper Susaa.

The ice border during this stage was situated along the so-called Giesegaard line and the meltwater left the ice at several points.

The more northerly of the many afflux to the river Susaa in this region, the brooks Vendebæk, Orned Bæk and Gillesbæk all seem originally to have been branches of a big glacier stream leaving the ice to the east of Haslev.

The ice lakes to the south of Testrup presumably at the same time drained to the north where the gorge to the NW of Testrup was eroded, and the bogs drained to Gillesbæk, while the outlet through Tyvelse Møllebæk gradually disappeared.

A further stage in the development of lake Tystrup Sø with a water level higher than to-day is to be seen at several places in the northern basin. By the northern shore a ridge isolated a small lagoon from the 
lake (fig. 1); this bog was quite overgrown with peat and is now dug out. Along the shore from Suserup Woods, across the river mouth and further on along the Nrsbyholm Woods, old cliffs are to be seen at several places, and the innermost part of the bay to the north of Flodevig is isolated from the lake by a bar.

\section{III}

\section{The Bottom Deposits in the Lakes.}

\section{a. General part.}

Samples of the bottom sediments were obtained by dredging between stations on the sounding traverses. A considerable number of the samples were taken to the laboratory for further examination, while the character of the others was determined on the spot by sieving through 0.2 and $0.5 \mathrm{~mm}$ sieves. In all about 200 samples were taken.

The dredge was used since it was the only means of obtaining samples suitable for petrographic analysis. The Ekman grab failed over and over again because shells or plant remains lodged between the jaws and prevented the grab closing, whereby the finer material was washed out before the grab came up. It was only used on pure mud bottoms. The Nauman sampling tube was also tried with the same result as with the grab. From pure mud bottoms with a water depth of 12-16 m, 15 cm long samples were taken, but they showed no difference between the upper and lower layers. The whole sample being a greybrown calcareous mud. In shallow water the apparatus failed completely.

The bottom samples brought to the laboratory were treated in different ways. Granulometric analysis by sedimentation in an Atterberg tube and elutriation was attempted in 1942 and 1943. The succeeding microscopic examination of the different fractions showed that the finer fraction in all samples consisted of aggregates of very fine calcite crystals, and this method was therefore abandoned because it gave a quite absurd picture of the mechanical composition of the samples, and was therefore of no value. Twenhofel came to nearly the same result from his investigations in Trout Lake, Wisconsin (Twenhofer 1945).

Sediments like those from lake Tystrup Sø containing considerable quantities of organic matter are rather difficult to examine. Once dried it is almost impossible to disperse them again. Mineral grains adhere to the plant remains, and small aggregates consisting of mineral grains cemented by fine, structureless organic matter are frequent. These aggregates have a grain size of about $1 \mathrm{~mm}$, and the result is that the coarser fractions dominate in the analysis. 


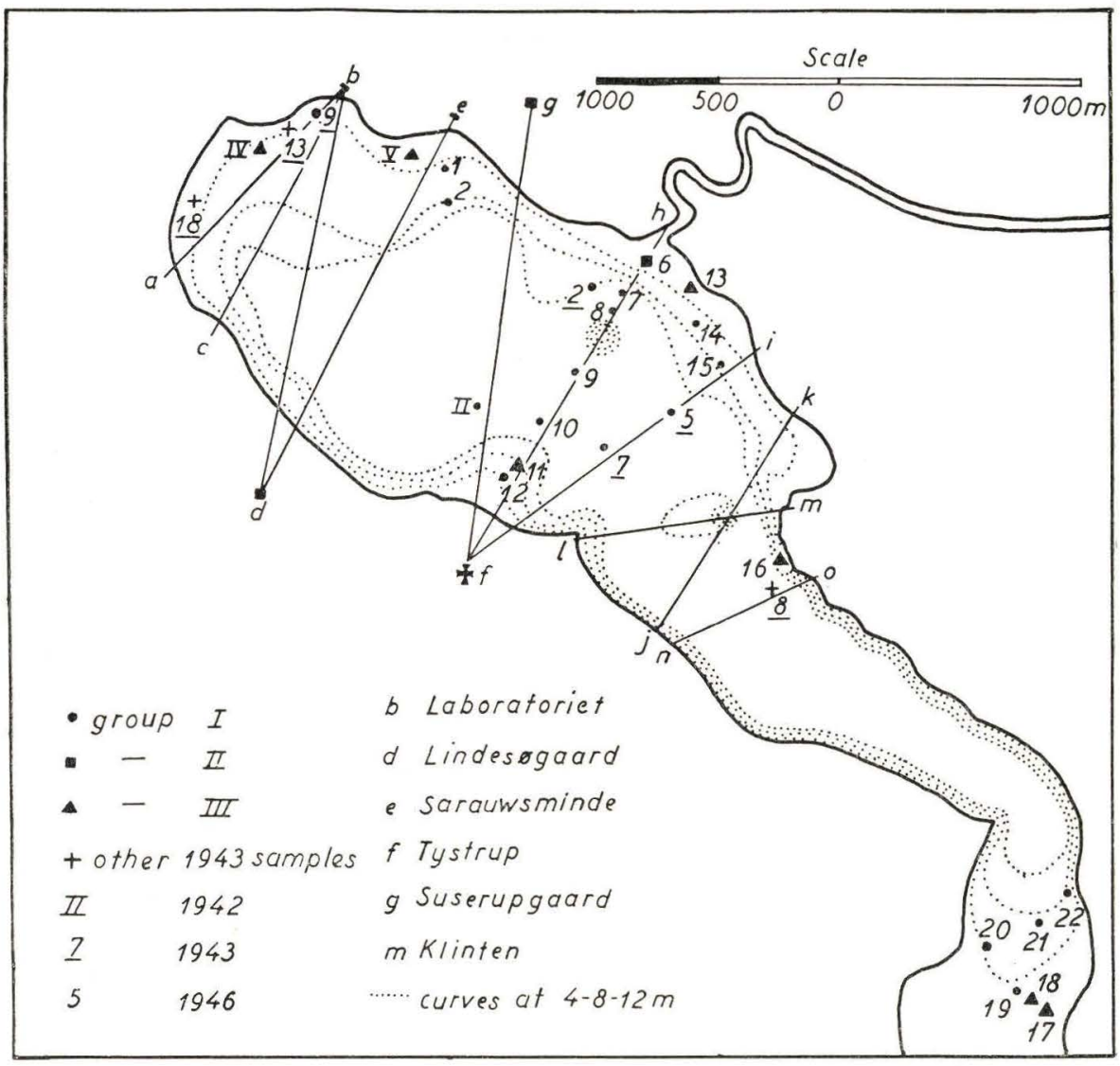

Fig. 14. Cross-sections and sampling stations in the northern basin of lake Tystrup So.

As these sediments also contain considerable amounts of calcite, a peptization by the addition of chemicals is a risky matter.

The granulometric analysis must therefore be made on wet samples whereby the control of accuracy is considerably weakened.

As these methods are not very accurate and take a very long time the samples taken in 1946 were treated in a simple way. They were sieved wet through 0.5 and $0.2 \mathrm{~mm}$ sieves, and the 3 fractions were dried and weighed. The results of this treatment are considerably more precise than those of a veritable granulometric analyse, and combined with a microscopic examination they are sufficent to show the structure of the lake sediments.

\section{The northern basin of lake Tystrup Sø.}

Table I presents the results of this procedure. In the samples from 1942 the fractions are arranged in the 3 main groups $>0.5 \mathrm{~mm}, 0.5-0.2$ 
Table I.

\begin{tabular}{|c|c|c|c|c|}
\hline \multicolumn{5}{|c|}{ Grain size fractions in bottom samples from lake Tystrup Sø } \\
\hline Sample No. & Water depth m & $<0.2 \mathrm{~mm}$ p.e. & $\begin{array}{c}0.2-0.5 \mathrm{~mm} \\
\text { p. } \mathrm{c}\end{array}$ & $>0.5 \mathrm{~mm}$ \\
\hline 1942 & & & & \\
\hline II & 12 & 98 & 2 & 0 \\
\hline IV & 5 & 7 & 6 & 87 \\
\hline $\mathrm{V}$ & 3 & 4 & 2 & 94 \\
\hline 1946 & & \multirow{2}{*}{\multicolumn{2}{|c|}{23}} & \\
\hline 1 & 4 & & & 73 \\
\hline 2 & 8 & \multicolumn{2}{|c|}{95} & 5 \\
\hline 6 & 1 & 12 & 78 & 10 \\
\hline 7 & 13 & 94 & 4 & 2 \\
\hline 8 & 13 & 94 & 4 & 2 \\
\hline 9 & 16 & 74 & 14 & 12 \\
\hline 10 & 14 & 85 & 13 & 2 \\
\hline 11 & 8 & 34 & 6 & 60 \\
\hline 12 & 7 & 60 & 29 & 11 \\
\hline 13 & 2 & 11 & 47 & 42 \\
\hline 14 & 5 & 81 & 18 & 1 \\
\hline 15 & 7 & 80 & 10 & 10 \\
\hline 16 & 2 & 2 & 38 & 60 \\
\hline 17 & 2 & 1 & 14 & 85 \\
\hline 18 & 2 & 14 & 21 & 65 \\
\hline 19 & 3 & 59 & 21 & 20 \\
\hline 20 & 4 & 51 & 22 & 27 \\
\hline 21 & 7 & 89 & 9 & 2 \\
\hline 22 & 9 & 77 & 16 & 7 \\
\hline
\end{tabular}

Table II.

\begin{tabular}{|c|c|c|c|c|}
\hline \multicolumn{5}{|c|}{ Bottom samples from 1943} \\
\hline Sample No. & Water depth $\mathrm{m}$ & $<0.2 \mathrm{~mm} \mathrm{p.c.}$ & $0.2-2 \mathrm{~mm} \mathrm{p.c.}$ & $>2 \mathrm{~mm} \mathrm{p.c.}$ \\
\hline 2 & 12 & 56 & 41 & 3 \\
\hline 5 & 15 & 98 & 2 & \\
\hline 7 & 16 & 86 & 1 & 13 \\
\hline$\delta$ & 12 & 25 & 69 & 6 \\
\hline 9 & 3 & 73 & 18 & 9 \\
\hline 13 & 2 & 44 & 46 & 10 \\
\hline 18 & 3 & 21 & 72 & 7 \\
\hline
\end{tabular}




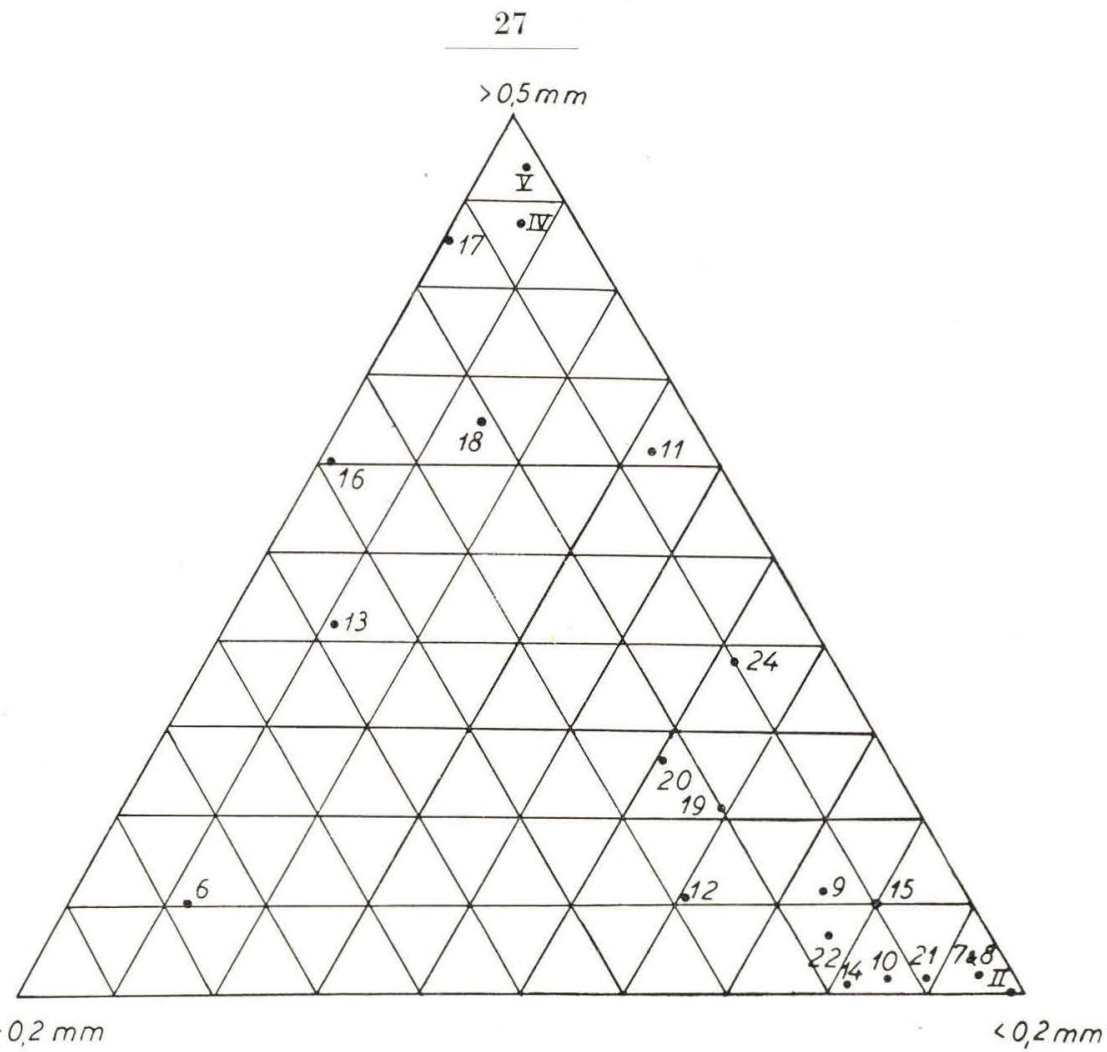

Fig. 15. Bottom samples from the northern basin of lake Tystrup Sø.

$\mathrm{mm}$ and $<0.2 \mathrm{~mm}$. It was necessary to arrange the samples from 1943 in other groups. The map fig. 14 shows the stations where the samples in the tables were collected.

Roman numbers indicate samples collected in 1942, and numbers underlined indicate samples collected in 1943. The rest of the samples were collected in 1946 .

To give an idea of the distribution in the different grain size groups, the analyses are arranged in a triangular diagram with the three components $<0.2 \mathrm{~mm}, 0.2-0.5 \mathrm{~mm}$ and $>0.5 \mathrm{~mm}$, and this results in a distribution into 3 natural petrographic groups (fig. 15).

Group I, samples having more than 50 per cent of the grains less than $0.2 \mathrm{~mm}$, includes samples 1942 . II and 1946 2. 7. 8. 9. 10. 12. 14. 15 . 19. 20. 21. 22. 24 .

Group II, samples largely in the range $0.2-0.5 \mathrm{~mm}$, includes the sample 1946. 6 .

Group III includes the samples 1942 IV and V, and 1946 11. 13. 16. 17. 18 .

An attempt to arrange the samples from table II in a triangular diagram gave no natural groups, which means that the system of classific- 
ation used in the table is unnatural for the material. The limits for a natural classification lie somewhere in the middle fraction, and the classification is too coarse for transposing to the system in table II by the help of a cumulation curve.

Even if it is not possible to classify these samples by the triangular diagram they can be dealt with in two natural groups.

A. The finest fraction dominates. This is the case in samples 2. 5. 7. 9. They are of nearly the same composition as group I in the triangular diagram and can be treated together with that group.

B. The coarse fractions dominate. This group includes samples 8,13 and 18 .

The enlarged group I (I and A) includes samples from all depths of water from $3-16 \mathrm{~m}$, and it can easily be seen that there is no direct relation between the size of the fraction $<0.2 \mathrm{~mm}$ and water depth or distance from the shore.

When fresh all these samples are a soft semi-liquid dark grey-brown mud. When dried they become lighter or darker dirty yellow-grey, cohering into larger or smaller clods, which can, however, be rather easily crushed to a fine powder between the fingers.

Under the microscope it can be seen that the finest fraction $(<0.2$ $\mathrm{mm}$ ) in all samples consists of fine calcite crystals or aggregates of these, fine structureless brown detritus and diatoms, together with some small dises of ealcite with a diameter of $0.016 \mathrm{~mm}$. Grains of quartz and clay minerals may be present, but they are only seen with great difficulty owing to their low bire'ringence, and their refractive index being very near to that of Canada balsam.

In the description of the coarser fractions it will be natural to divide the samples into several sub-groups according to their position on the lake bottom (fig. 14).

The first of these sub-groups includes the samples 1942. II, 1943 2. 5. and $\%$. and 1946 2.7.8.9. 10 .

The sample 1942 II is pure mud. The fraction $0.2-0.5 \mathrm{~mm}$ consists of only a few quartz grains and ostracod shells composing not more than 2 per cent of the sample, while components coarser than $0.5 \mathrm{~mm}$ are quite lacking.

In the samples 19432.5 . and $\%$. the fraction $0.2-2 \mathrm{~mm}$ consists of very varied, but mostly organogenic components. Shells of ostracods constitute the main part, but various plant remains and the exoskeletons of zooplantonic organisms play a considerable role. Quarts-grains are present, but are of very subordinate importance. The coarser components are of the same character, but sample $1943 \%$. has, however, a few small stones.

In the samples 1946. 7 and 8 the fraction $0.2-0.5 \mathrm{~mm}$ has a composition 
similar to the preceding samples. The fraction $>0.5 \mathrm{~mm}$ consists only of plant remains such as fragments of leaves, stems and fruits.

Samples 1946. 9 and 10 are peculiar in containing iron pisolites (iron shots). In the sample 19469 , the main part of the fraction $0.2-0.5$ $\mathrm{mm}$ is composed of small spherical or ovate bodies. Some of them consist of calcite grains cemented by limonite and are in reality small clods of mud, but the main part is a real iron ore. The ore makes up nearly 90 per cent of the fraction, which also contains a subordinate number of ostracod shells and a few fragments of lamellibranch shells. Plant remains are not to be found.

The fraction $>0.5 \mathrm{~mm}$ also consists largely of pisolite ore with some shells and shell fragments as a subordinate part, but no plant remains.

The sample 1946. 10 contains a smaller quantity of ore than the preceding sample, but the constitution of the fraction $0.2-0.5 \mathrm{~mm}$ is otherwise the same. In the fraction $>0.5 \mathrm{~mm}$ shell fragments dominate while plant remains are present, but only in very subordinate numbers.

The sample 1942. II. cannot be compared with the other samples in the same way, as it is only sieved thorough the $0.5 \mathrm{~mm}$ sieve, but the microscopic examination shows that it must belong to group I. It differs somewhat in appearance from the other mud samples. When fresh it is a black coherent mud; when dried the fraction $<0.5 \mathrm{~mm}$ is very dark brown and consists of calcite crystals, a large amount of fine organic detritus, some ostracod shells and pisolite ore. The fraction $>0.5 \mathrm{~mm}$ consists of shell fragments, pisolite ore and small clods of light blue vivianite.

A comparison of these descripitions with the observations made during the sounding and dredging shows that the bottom of the lake valley is covered by a grey-brown semi-liquid calcareous mud. At most of the stations the $0.5 \mathrm{~mm}$ sieve only contained small soft clods of mud, a few snail shells and a little pisolite ore. At depths of more than $8 \mathrm{~m}$ the sediments are almost exclusively of chemical and organogenic origin, perhaps with a greater or lesser amount of clay with a grain size of less than $0.01 \mathrm{~mm}$, which cannot be distinguished under the microscope.

The elements coarser than $0.2 \mathrm{~mm}$ are plant drift which has sunk to the bottom, together with the remains of planktonic organisms.

The second sub-group of samples includes the samples 12, 14 and 15 situated at depths of 4-8 $\mathrm{m}$ on the slope to the bottom of the basin.

In the sample 194615 . the fraction $0.2-0.5 \mathrm{~mm}$ has the same composition as the samples of the first sub-group, but the fraction $>0.5$ consists for the main part of pisolite ore together with some shells and shell fragments, but almost without plant remains.

In the sample 1946. 12 terrigenic material plays a considerable part 
in the coarse fractions. Here quartz grains dominate over the organogenic components.

This, together with observations during dredging, indicates that from depths of $4-5 \mathrm{~m}$ the calcareous mud begins to dominate in the dregde samples, and at depths greater then $6 \mathrm{~m}$ the dredge is almost always filled with a semi-liquid grey-brown mud which only by sieving wet through the $0.5 \mathrm{~mm}$ sieve is shown to contain coarser components.

Along the Næsbyholm Woods these coarse components are on the whole coarse detritus, but at a few places opposite the point between the two bays, samples from a water depth of $7 \mathrm{~m}$ contain a few plant remains, while shell fragments and small black spheres (pisolite ore) dominate.

On the slopes of the bank Aagabgrunden from the top to a depth of $7 \mathrm{~m}$ the dredge contained living and dead Anodonta and clumps of living Dreissensia.

The slope of the broad shoal opposite Suserup woods is covered with pure mud with a little vivianite at some stations. Pisolite ore is very common.

On the Tystrup side of the lake the bottom at depths greater than $5 \mathrm{~m}$ is exclusively covered by calcareous mud.

Some of the samples from the threshold between the northern and southern basins of Tystrup lake may be added to group I. These are samples 1946 19. 20. 21 and 22. taken at depths varying from 3-7 m.

In these samples the fraction $0.2-0.5 \mathrm{~mm}$ has in all cases the same composition as those from the northern basin. The sample 194620 , however, contains more abundant quartz grains. The fraction $0.2-0.5$ $\mathrm{mm}$ is more variable. In the sample 1946 19. the shell fragments dominate and plant remains are more subordinate. In the samples 194620 . and 22. it is the plant remains which dominate, but some shells and shell fragments are also to be found. In the sample 1946 21. the fraction is composed exclusively of plant remains such as fragments of leaves, stems and fruits.

The sample 1946. 20. is taken from a black area on the otherwise light lake bottom with a water depth of $4 \mathrm{~m}$. Disturbed by the oar a cloud of black mud rose from the area, which is a local accumulation of partly decayed vegetation.

The groups II and III both include samples taken at depths of less than $5 \mathrm{~m}$ on the shoal and along the shore, together with a few from deeper water.

Group II includes the sample 1946. 6. but to this may be added the samples 1943 8.13.18.

The sample 1946 6, is taken in the mouth of river Susaa and gives a clear impression of this. The finest fraction, $<0.2 \mathrm{~mm}$, is not a pure 
calcareous mud as in most of the other samples, but consists of fine clay and quartz together with fine structureless organic detritus. The sample is otherwise sandy, and small grains of quartz play a dominant role. Calcite is nearly only to be found as shell fragments or as small tubes. Plant remains are present in large numbers, partly as fine detritus and partly as fragments of stem and root.

The sample 19438 . is taken at the northern end of the narrow part of the lake with a water depth of $12 \mathrm{~m}$ and is a somewhat sandy mud. The finest fraction is the usual calcareous mud. The fraction $>0.2 \mathrm{~mm}$ is a heterogenous mixture of shells, shell fragments, quartz grains and small fragments of rock. Plant remains are very scarce.

The samples 1943 13. and 18 were taken on the shoal in the northern end of the lake with water depths of 2 and $3 \mathrm{~m}$. Both contain large quantities of calcareous mud, respectively 44 and 22 per cent. The coarser fractions are somewhat different in the two samples. In the sample 1943 13. quarts grains are lacking and the coarser components consist of shell fragments and a little pisolite ore. These two samples contain plant remains only in very small quantities, if at all.

Group III includes the samples 1942. IV and V and 1946. 11. 13. 16. 17. 18.

The sample 1946. 11. was taken on a shoal to the north of Tystrup with a water depth of $8 \mathrm{~m}$. The sample has a very heterogenous composition. When fresh it is a semi-liquid detrital mud with innumerable stones of the size of a fist, some shells of Anodonta and plant remains. Under the microscope it is seen that the fraction $0.2-0.5 \mathrm{~mm}$ contains quartz grains, ostracod shells, molluscan shell fragments, chitinous remains and some plant remains. The fraction $>0.5 \mathrm{~mm}$ consists exclusively of shells of Dreissensia and Anodonta, and stones.

This composition resembles that of sample 1946. 12, and differs considerably from the usual composition of bottom samples from this depth. The reason is probably that the sample is taken from a gravel terrace where the deposition of fine mud is for some reason impeded; almost the same thing is to be seen on Aagabgrunden and on the bank opposite Klinten in the Næsbyholm Woods. The samples 1942. IV and $\mathrm{V}$ were taken in shallow water on the shoal in the northern end of the lake. The sample 1942 IV is sand with Dreissensia. The finest fraction, $<0.2 \mathrm{~mm}$, contains several small quartz grains and the usual calcareous mud. The fraction $0.2-0.5 \mathrm{~mm}$ is quartz sand with several shell fragments and some plant remains. The fraction $>0.5 \mathrm{~mm}$ is composed mostly of terrigenous components such as small rolled quarts grains, rolled fragments of rocks and pisolite ore, especially in the coarser part of the fraction.

The sample 1942. $\mathrm{V}$ is a gravel with shells. The fraction $<0.2 \mathrm{~mm}$ 
has a similar composition to the preceding sample, but with more plant remains. The fraction $0.2-0.5 \mathrm{~mm}$ is composed almost exclusively of coarse organic detritus. The fraction $>0.5 \mathrm{~mm}$ has a similar composition to that of the sample 1942. IV, but without the pisolite ore and with more plant remains.

With these two samples must be connected the sample 1946. 1, composed of shells of Anodonta and fine sandy detritus. The fraction $<0.5 \mathrm{~mm}$ has the same composition as in the two preceding samples, but in the fraction $>0.5 \mathrm{~mm}$ the greater part is composed of shell fragments and pisolite ore. Other mineral components are quite subordinate.

The samples 1946. 13 and 16 were taken opposite the Næsbyholm Woods, likewise in shallow water. The sample 1946. 13 is a detrital sand with many small shell fragments, empty shells of Anodonta and living Dreissensia. The fraction $<0.2 \mathrm{~mm}$ is, as in the other samples from shallow water, a fine quartz sand with much calcareous mud. The fraction $0.2-0.5 \mathrm{~mm}$ is for the greater part composed of quartz grains with some shell fragments and the fraction $>0.5 \mathrm{~mm}$ has the same composition.

The sample 194616 , taken in the narrows, is gravel with stones the size of a fist. The fraction $<0.2 \mathrm{~mm}$ is composed of quartz grains and shell fragments mixed with calcareous mud. The fraction $0.2-0.5$ $\mathrm{mm}$ is composed almost exclusively of rolled quartz grains, and the fraction $>0.5 \mathrm{~mm}$ has the same composition, but with some stones and shell fragments.

The samples 1946. 17. and 18. were taken on the threshold in the southern end of the narrows and have the same composition as sample 1946. 13 in all fractions.

With this group of samples is included sample 1943. 9. In this the fraction $0.2-0.5 \mathrm{~mm}$ is composed of a heterogenous mixture in which plant remains dominate, but there are also several tubes built of cemented calcite grains, exoskeletons, egg capsules and fragments of snail and lamellibranch shells.

As a summary of the investigations in the northern basin of lake Tystrup Sø it may be said that in the shallow water along the shore, on the shoal and on the banks the bottom deposits are of varying composition, and the limits between the different types of sediments are situated at different depths in different parts of the lake.

Along the Nrsbyholm Woods the shallow water $(0-2 \mathrm{~m})$ bottom is a fine sand with numerous small reed fragments, snail shells, empty shells of Anodonta and living Dreissensia. A number of scattered stones also occur. At depths of $2-4 \mathrm{~m}$ the dredge for the main part brings up clumps of Dreissensia and empty shells of Anodonta. At a few places a detrital shell sand is found. On the bank off Klinten, and on the lake 
bottom along Klinten, sand, gravel and stones are also the normal sediment.

From the mouth of river Susaa to the south-eastern corner of the Suserup Woods the lake bottom slopes rather steeply. In the mouth of the river and off this at depths up to $2 \mathrm{~m}$ the lake bottom is fine sand, with 90 per cent passing the $0.5 \mathrm{~mm}$ sieve. The coarser components form a heterogenous mixture of quartz and other mineral grains, small rock fragments, calcite aggregates and shells of molluses and ostracods, together with fruits, and other plant remains, among which leaves of Nymphaea are numerous. The calcite aggregates are often present as small clods, but also occur as small tubes built up by larvae. The shells of living and dead Anodonta with Dreissensia attached to them are also frequent. On the bank Aagabgrunden the dredge brings up a little coarse sand and gravel together with shells of Anodonta, clumps of Dreissensta and plants.

Along the shore between the mouth of river Susaa and the Suserup Woods the bottom to a depth of $1.5 \mathrm{~m}$ has a regular pavement of large stones, nearly all covered with dense algal vegetation and thick calcite encrustations.

On the broad shoal in the northern end of the lake the sediments are of varying composition. On the eastern part of the shoal, with water depths of $0-3 \mathrm{~m}$ the bottom is a calcareous mud with numerous shells of snails and lamellibranchs, and stones of the size of a fist. In deeper water the stones are absent. In the fraction $<0.2 \mathrm{~mm}$ the shells of ostracods dominate, but organic detritus in the form of fragments of stems, leaves and fruits makes up a considerable part of the deposit. Some of the shells are quite clean and smooth, but others are strongly iron-encrusted. Some of the plant remains also have iron crusts Lake ore, pisolite ore, is also present, as well as concretions. Vivianite is present in rather considerable quantities as very small crystals. Farther west on the shoal the bottom is for the most part softer, and composed of finer muddy sand with detritus and shells. The sandy components are mostly shell fragments, and the content of sand grains is in some places very low.

Opposite the spring field in the Frederikskilde Woods the brooks transport some sand out into the lake forming small deltas (Fig. 16 and 17), and farther out the bottom may be rather hard and sandy. Here in the very shallow water there are numerous stones with thick calcite encrustations. The western part of the spring field yields strongly ferruginous water, and the iron is deposited on the vegetation as powdery aggregates (ochre) or on the beach stones as iron crusts. In the lake, however, all the stones have calcite crusts. 


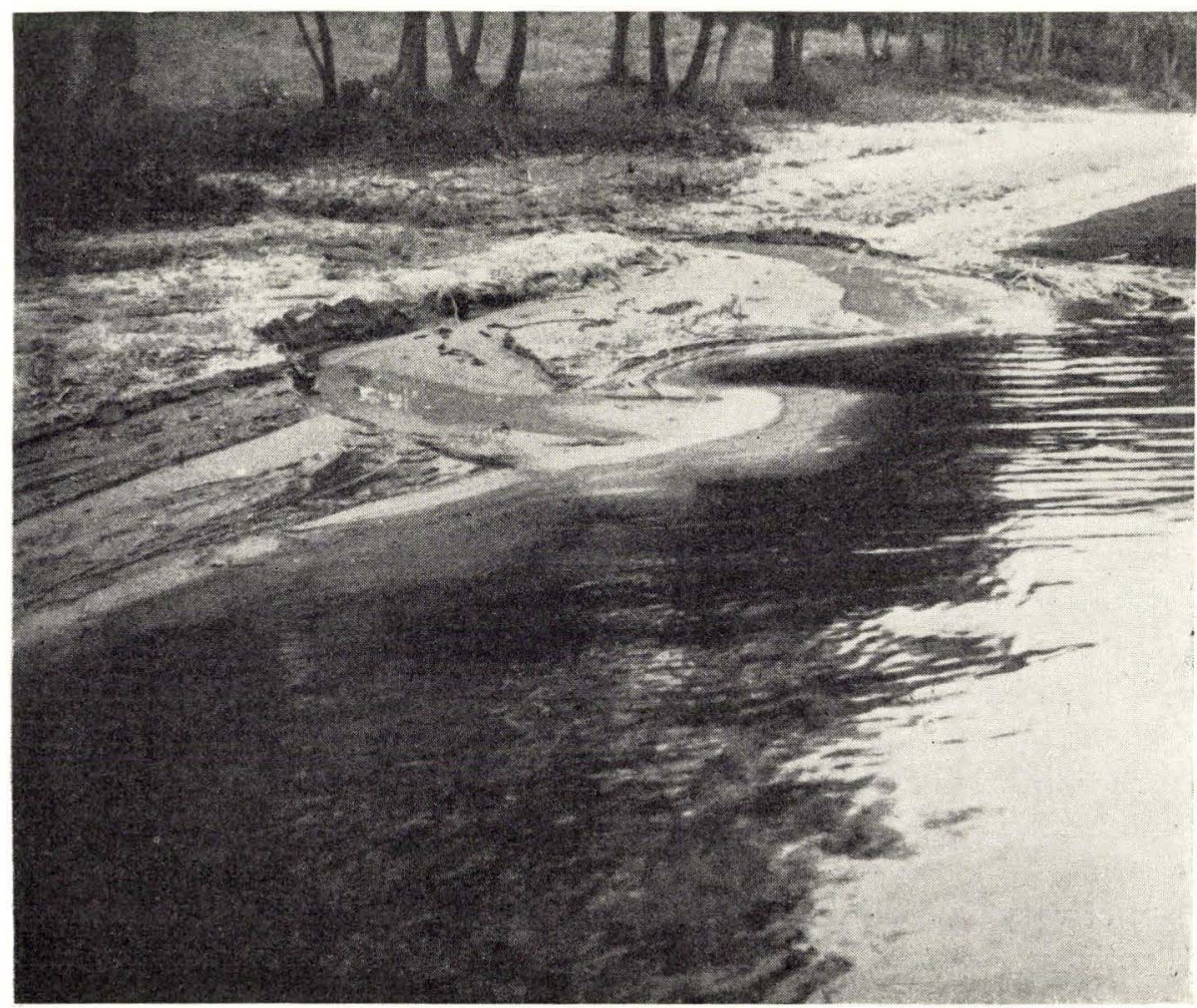

Fig. 16. The outlet of brooks into the northern end of lake Tystrup Sø.

Farther out on the shoal at depths of more than $3 \mathrm{~m}$ the calcareous mud begins to maintain itself as a bottom deposit, molluscs are, however, present in great numbers to a depth of $4 \mathrm{~m}$, and on the outermost bank of the shoal there are molluscs at a depth of up to $6 \mathrm{~m}$. Otherwise the calcareous mud apparently predominates from a depth of $5 \mathrm{~m}$, and outside this limit shells are only present at a few places. The shells here are for the greater part encrusted with limonite and all transitions from clean, iron-free shells to pure lake ore are to be found.

If, however this mud is, sieved wet through the $0.5 \mathrm{~mm}$ sive there will remain a heterogenous mixture of animal and plant remains in the sieve, but minerogenic components will be very scarce.

Along the Tystrup side of the lake to a depth of $4 \mathrm{~m}$ the lake bottom is more minerogenic. Off the esker in the Kjellerød Woods the bottom at a depth of $3 \mathrm{~m}$ is composed of gravel with shells of Anodonta and Dreissensia. In other places, where the lake bottom slopes steeply, a brown or black very detrital calcareous mud is present at the same depth, together with plant remains. 


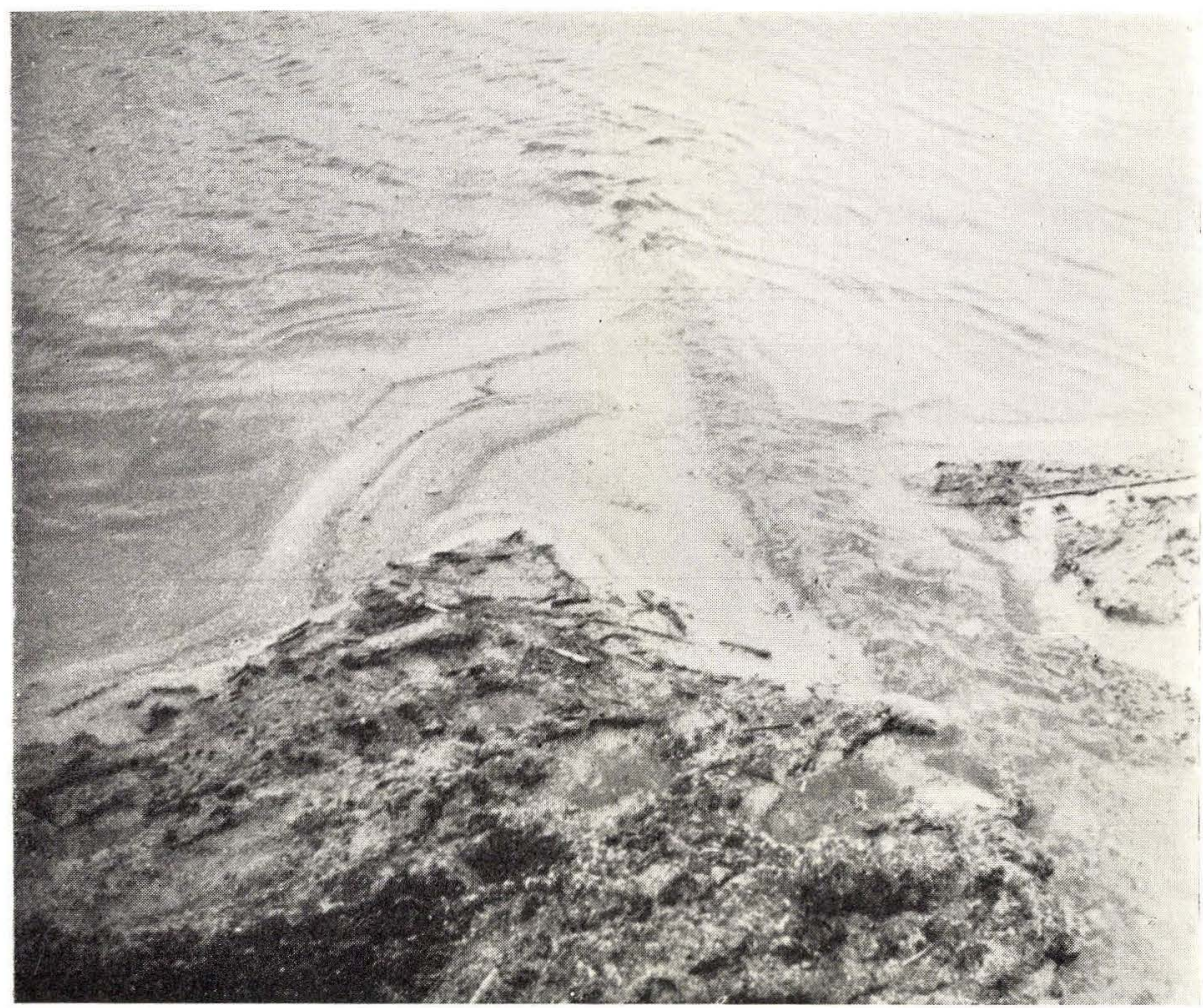

Fig. 17. Small deltas in the northern end of lake Tystrup Sø.

On the shoal between Lindesøgaard and Tystrup the bottom is sandy with shells and plant remains to a water depth of $4 \mathrm{~m}$, but from 5 $\mathrm{m}$ the bottom is covered with pure calcareous mud.

Off Tystrup the bottom is very terrigenous to a depth of $11 \mathrm{~m}$. On the eastern side of the point near Tystrup there is gravel to a depth of $4 \mathrm{~m}$, and farther out calcareous mud.

\section{The southern basin of lake Tystrup Sø.}

The investigations here are rather less detailed than in the northern basin, but the character and distribution of the sediments is almost the same.

In the shallow water close to the shore the bottom is very stony, the stones being covered with algae and thick calcite encrustations. Farther out black muddy sand follows to a water depth of $5 \mathrm{~m}$, and to this depth many empty shells of Anodonta are found together with a few living Anodonta and clumps of Dreissensia. In deeper water ealcareous mud predominates, as in the northern basin. 


\section{The lake Bavelse Sø.}

The bottom conditions seem here a little different from those in lake Tystrup Sø, but the investigation here has unfortunately not been very thorough. Samples were taken in a cross section from Bavelse church to Gunderslevlille on the southern shore, and also at a few places in the western part of the lake. The shoal at the eastern end of the lake was not investigated.

From depths of $0-5 \mathrm{~m}$ the dredge brought up sand with plant remains and shells of Anodonta and Dreissensia. From the flat lake bottom with a water depth of $5-8 \mathrm{~m}$ the most common deposit was the usual grey-brown mud whose fraction of $<0.2 \mathrm{~mm}$ only contained some few plant remains, shells of ostracods, chitinous remains and some white calcareous concretions probably originating from the Characeae. These are rather loose and porous, but, however, harder than the usual small clods of the grey calcareous mud, differing clearly from these in their snow-white colour. In spite of the rich and dense vegetation of Chara in this lake none of the small calcareous tubes so characteristic of Chara limestone were found.

In the sample from the slope to the southern shore of the lake there were several quartz grains and shells of Dreissensia in the mud.

In the western end of the lake a sample was taken a little to the east of the channel to lake Tystrup Sø; here the dredge contained only the same calcareous mud, and in the $0.5 \mathrm{~mm}$ sieve there remained only organic detritus

The mud in lake Bavelse Sø is a little more organogenic than that in lake Tystrup Sø.

\section{b. Special part.}

\section{The calcareous mud.}

As mentioned on the preceding pages the finest fraction $(<0.2 \mathrm{~mm})$ in all the samples consists of fine calcite crystals, or aggregates of these, brown structureless detritus and diatoms, together with some quartz and clay substance.

The calcite crystals are always columnar, never rhombohedral. The length of the primary crystals is about $5 \mu$, but frequently these are surrounded by a zone of secondary calcite with the same optical orientation as the primary crystal. These grains have a length of $20 \mu$ and are frequently club shaped or pear shaped, thicker at the one end than at the other.

Further information as to the character of the mud is given by two chemical analyses made by Civil engineer Miss M. L. Mouritzen, chemist to the Mineralogical Museum in Copenhagen. 


\begin{tabular}{|c|c|c|c|c|c|c|}
\hline \multirow[b]{3}{*}{$\mathrm{SiO}_{2}$} & \multicolumn{3}{|c|}{37} & \multirow{2}{*}{\multicolumn{3}{|c|}{ Sample 1946. 10}} \\
\hline & \multicolumn{3}{|c|}{ Sample 1946. 9} & & & \\
\hline & 33.67 & per & cent & 21.41 & per & cent \\
\hline $\mathrm{Al}_{2} \mathrm{O}_{3}$ & 4.59 & - & - & 3.13 & - & - \\
\hline $\mathrm{Fe}_{2} \mathrm{O}_{3}$ & 4.70 & - & - & 3.88 & - & - \\
\hline $\mathrm{CaO}$ & 23.94 & - & - & 31.94 & - & - \\
\hline $\mathrm{P}_{2} \mathrm{O}_{5}$ & 0.85 & - & - & 0.85 & - & - \\
\hline
\end{tabular}

The quantity of $\mathrm{CaO}$ corresponds to 43 and 58 per cent $\mathrm{CaCO}_{3}$ respectively. Several other carbonate determinations showed a $\mathrm{CaCO}_{3}$ content of $35-55$ per cent.

The $\mathrm{SiO}_{2}$ corresponds to a content of quartz or clay, and the diatoms. As the microscopic examination shows, these play a very subordinate role, but if only $\mathrm{I} / 3$ of the $\mathrm{SiO}_{2}$ is calculated as originating from the diatoms the proportion between $\mathrm{Al}_{2} \mathrm{O}_{3}$ and $\mathrm{SiO}_{2}$ will be $5: 22$ and $3: 14$, while the proportion from the general kaolinite formular is $4: 5$.

Even if it be assumed that the clay substance in the mud is not kaolinite, but aluminious silicates with a greater content of $\mathrm{SiO}_{2}$ there will be a considerable surplus of $\mathrm{SiO}_{2}$ in proportion to the $\mathrm{Al}_{2} \mathrm{O}_{3}$ and this must be present as quartz.

There is only one term in English for such a sediment: it is calcareous mud. In the Scandinavian languages several terms are used and the sediment here may be called a Kalkgytje. LUNDQUist writes (1927) that in Søkalk and Kalkgytje the calcite is visible macroscopically, and that when the calcite content is less than 10 per cent only a white powdering is to be seen. The Kalkgytje deposited in lake Tystrup Sø does not satisfy this condition. Neither fresh nor dried do the samples show any sign of a large calcite content. This is only to be seen under the petrological microscope. WESENBERG LUND proposes (1901) the following classification of limnic calcareous sediments.

Outside the $11 \mathrm{~m}$ curve $20-80$ per cent $\mathrm{CaCO}_{3}$ Kalkgytje

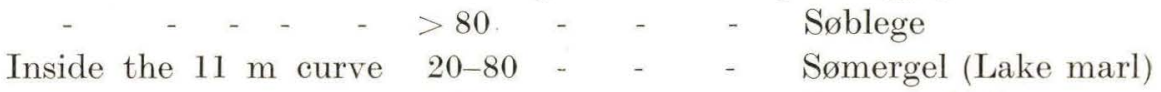

$>80 \quad-\quad$ - Characeekalk

Mollusk-kalk

The basis of this classification is that calcareous deposits inside and outside the $11 \mathrm{~m}$ curve are of different origin. According to WESENBERG LUND the calcareous deposits inside the $11 \mathrm{~m}$ curve originate for the main part in the powdered shells of lime-producing organisms living in the area, while the calcareous deposits outside the $11 \mathrm{~m}$ curve originate in the mechanical sedimentation of floating calcite particles, or by chemical precipitation of $\mathrm{CaCO}_{3}$ from the lake water.

From a petrographical point of view such a classification, which is 
based on regional distribution, is very unfortunate. A rock name must refer to the petrographical qualities and only to these, not to the regional distribution of rocks of the same petrographic character. But in lake Tystrup Sø it is furthermore the 5 or $7 \mathrm{~m}$ curve, not the $11 \mathrm{~m}$ curve, which is the boundary between the deposition of more or less powdered molluscan shells on the one side, and chemically or planktonically precipitated calcite on the other.

A sedimentary rock such as the present, consisting of about 50 per cent $\mathrm{CaCO}_{3}, 20-35$ per cent clay and 15-30 per cent organic matter may be classified either as a Kalkgytje or a Sømergel (Lake marl), preferably the former, without regard to the depth at which it is found.

Concerning the origin of the calcareous mud it is rather difficult to say anything definite; it may either be a pure clastic sediment or it may be the result of chemical or organic precipitation, or a mixture of both.

In a clastic sediment the calcite grains in the mud may be derived from:

1. the crushed shells of molluses transported as a fine powder to deeper water.

2. calcite grains originally deposited on the surface of macrophytes or Characeae.

3. the crushing of the calcite crusts on stones in shallow water by wave action.

The large amount of shell sand in the samples from the shoal between the Suserup Woods and Frederikskilde indicates that crushing of the shells of both gastropods and lamellibranchs takes place, and there is no doubt that this is a very important source of the calcite grains in the mud.

Calcite grains derived from lime precipitation on the surface of macrophytes do not play any role at present in lake Tystrup Sø. It is extremely unusual to find such lime crusts on the macrophytes, and the Characeae are so few in lake Tystrup Sø that they are of no consequence for the calcite content of the lake bottom.

On the other hand there is a very rich characeous vegetation in lake Bavelse Sø, and it is curious that the bottom sediment here has nearly the same petrographic character as in lake Tystrup Sø and that the small calcite tubes so characteristic of Characeae are never found.

The calcite crusts on the stones, which will later be further described, probably form an important source of the calcite in the mud.

As mentioned previously, many of the calcite crystals in the mud are sourrounded by zones of secondary growth. This indicates that calcite deposition takes place on the lake bottom after the original crystal has been formed, and it is not to be excluded that a biogenic 
or abiogenic precipitation of calcite from the water in the lake takes place. Brøndsted and Wesenberg Lund (1912) found the following quantities of $\mathrm{CaO}$ in the water.

Susaa upstream of the outlet into lake Tystrup sø.. $103.1 \mathrm{mg} / 1 \mathrm{CaO}$

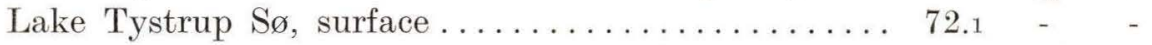
Susaa downstream from lake Bavelse Sø....... 92.7 -

Some of the $\mathrm{CaO}$ lost from the Susaa water is probably used by molluscs and the algae in producing shells and calcite encrustations on the stones, but further possibilities are present, for example, pure abiogenic precipitation, or biogenic precipitation of calcite by bacteria or planktonic organisms.

The abiogenic precipitation of calcite indicates that the water, saturated with soluble calcium bicarbonate, $\mathrm{Ca}\left(\mathrm{HCO}_{3}\right)_{2}$, has been subjected to a further increase in concentration either as a result of evaporation, or loss of $\mathrm{CO}_{2}$ to the atmosphere in consequence of a change in the $\mathrm{CO}_{2}$ pressure or by an increase of the water temperature.

PIA (1933) states that it is very difficult to determine whether a pure chemical precipitation really takes place in the lakes as the bicarbonate tends to become supersaturated without precipitation, and that the other salts or the suspended particles have a rather important effect on the solubility of the bicarbonate. It must also be borne in mind that the precipitated calcite will probably be dissolved again on the way to the bottom when it reaches the cooler, more carbon - dioxide-rich water below the thermocline (JoHnston and WILLIAMSON 1916 KaJ HaNSEN 1945 b).

Altogether the conditions in lake Tystrup Sø seem to be in opposition to KINDLE's assumption that calcareous mud should not be produced in larger lakes because these have not the thin upper layer of warm water saturated with calcium bicarbonate (KINDLE 1929). The distribution of temperature in the lakes plays no great part in the production of calcareous sediments. These depend in some degree on other factors amongst which the presence of lime producing organisms is probably the most important.

\section{The iron ores.}

As is to be seen from the map, fig. 18, lake ore is found in the bottom sediments both in shallow water and at the greatest depths in the lake. It occurs in two forms, pisolite ore, and iron concretions corresponding to Naumann's term 'Skragg' (Naumann 1922).

The pisolite ore seems always to originate in iron-encrusted mud, the concretions being formed by iron precipitation on molluscan shells, and as previously stated by Wesenberg Lund (1901), it is almost 


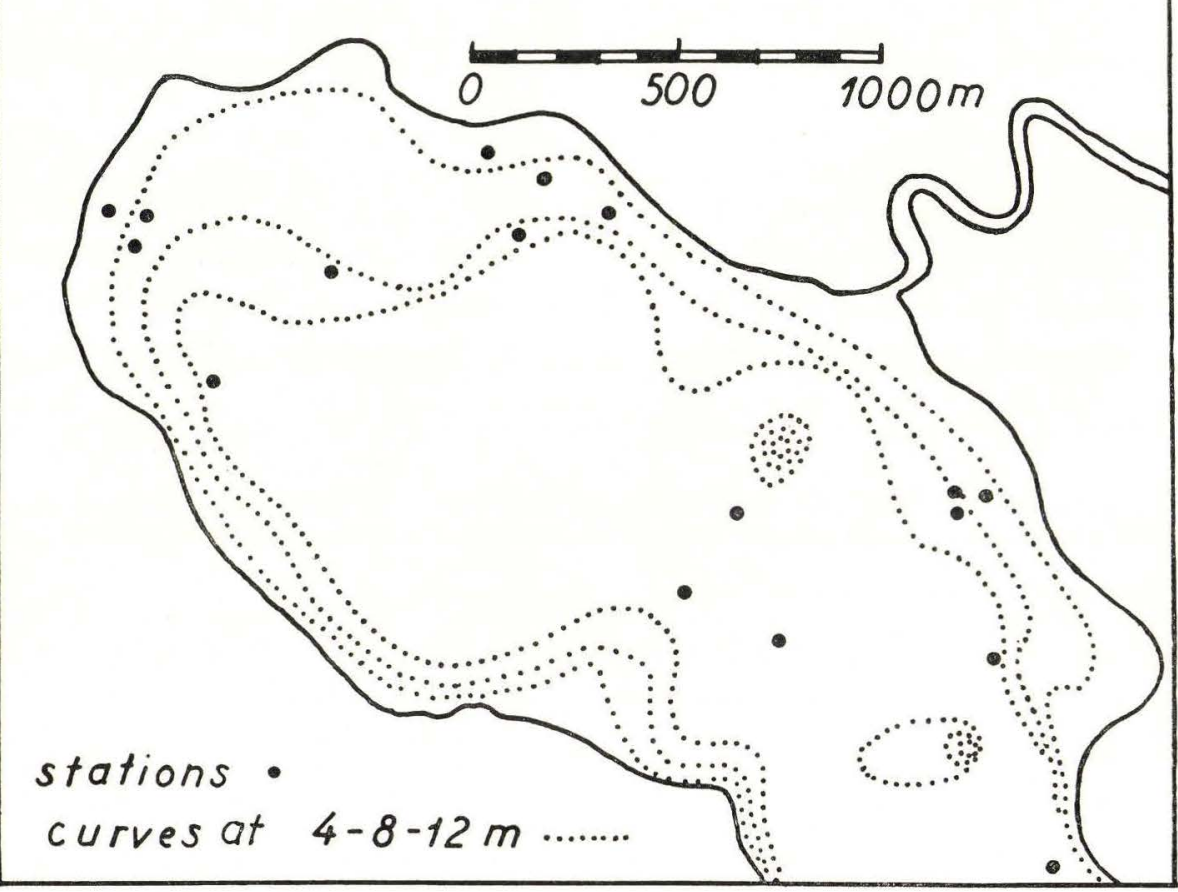

Fig. 18. Stations with lake ore.

exclusively shells of Anodonta and Unio which have been encrusted in lake Tystrup Sø, while the shells of other lamellibranchs and snails hardly ever show any sign of iron precipitation.

The concretions are usually flat or lense-shaped. They vary very largely in size, the largest one found during these investigations being $23 \mathrm{~cm}$ long, $9 \mathrm{~cm}$ wide and $1,5 \mathrm{~cm}$ thick in the middle. Some of them are very friable and break very easily, others are very hard and solid.

They are very often formed as encrustations on Anodonta shells, and all transitions from shells with only a thin layer of limonite on the outside to concretions where the shell is almost completely lost, are found (Fig. 19 and 20).

It seems that precipitation of iron always starts, and is most intense on the outside of the shell round the umbo. Shells are very often found with a white and shiny inner surface, while the outside and edges are covered by a layer of limonite a few millimeters thick. Thick wrinkles are found particularly on the foremost and upper part of the edge of the shells, whereas the rest of the outside of the shell is only partially covered by the iron encrustation, and the inside is totally free.

The reason for this may be that the loose shells are mostly lying on the lake bottom with the arched side up (RICHTER 1921), so this 


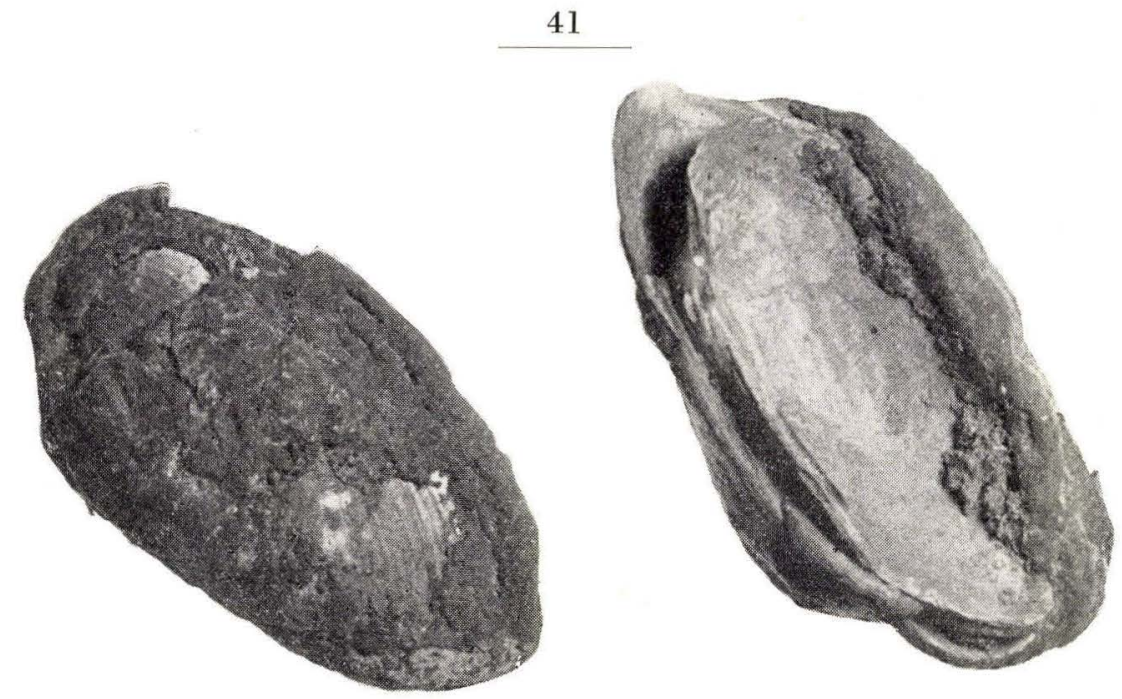

Fig. 19. Anodonta shells with the beginning of iron encrustation.
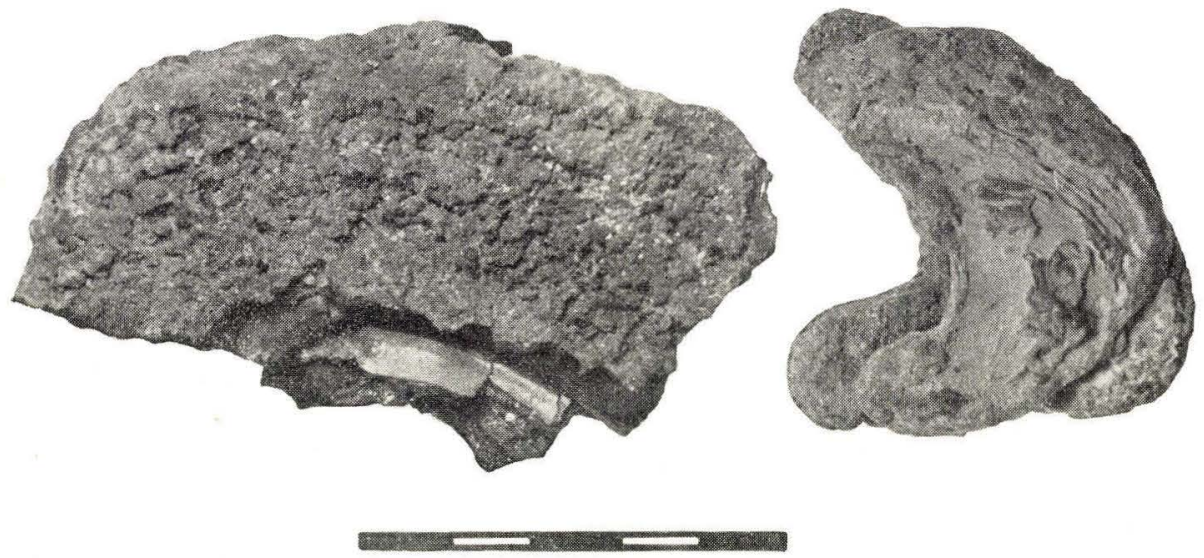

Fig. 20. Iron concretions, where the shell has mostly disappeared.

side is the more exposed to precipitation of the iron dissolved in the lake water.

The iron ores have strongly varying colours: yellow-brown, red-brown or black. It appears that the yellow-brown colour is the first and the black the last stage, since there is always a thin layer of yellow-brown or red-brown limonite on the outside of the crust.

In most of the encrusted shells the prismatic layer is lost; it seems as if this layer is less resistent than the lamellar layer.

Wesenberg Lund (1901) states that the iron ore originates not 
only in preciptiation on the outside of the shell, but also that calcite is replaced by limonite. A polished cross-section (embedded in sealing wax) of such a concretion containing a shell fragment shows that the limonite penetrates between the prisms and separates them. Other thin limonite sheets push themselves straight through the prisms, which crumble away so that the prismatic layer gradually becomes replaced by thin lamellae of iron corresponding to the lamellar layer of the shell.

From the prismatic layer the iron may penetrate further between the different lamellae in the lamellar layer and replace the calcite by limonite.

In some of the concretions no shell arise visible, and it seems as though there has never been any. These concretions give the impression of being iron encrusted portions of the lake bottom. Only sand is to be seen inside the iron crust when this is broken open.

In these concretions there are irregular tubes and cavities more or less filled with quartz grains, shells of ostracods and crushed fragments of lamellibranch shells. The heterogenous contents of the cavities in the concretions are all quite clean on the surface, without any iron precipitation in spite of the fact that they are situated in the middle of an iron concretion.

The iron content is rather high. Two analyses made by Miss Mouritzen give the following results:

Pisolite ore $\ldots \ldots \ldots \ldots \ldots \ldots . \ldots .23$ per cent $\mathrm{MnO}$. 45.83 p. c. $\mathrm{Fe}_{2} \mathrm{O}_{3}$ Iron concretion $\ldots \ldots \ldots \ldots \ldots .5 .31$ per cent $\mathrm{MnO} .64 .90$ p. c. $\mathrm{Fe}_{2} \mathrm{O}_{3}$

The quantities in the concretions are very nearly as large as in the most iron-rich Swedish lake ore (NAUMann 1922), and are also rather near the iron content of the Minette ores from Lorraine in France. (AREND 1932).

The pisolite ores in lake Tystrup Sø are mostly situated at depths greater than $10 \mathrm{~m}$. The shape may vary from almost spheroidal to more or less irregular. The pisolites are always iron encrusted calcareous mud, but their structure is very variable.

Some of them have only a thin crust of limonite traversed by numerous fissures. Within the crust is a more or less hard, granular nucleus built up of iron encrusted calcareous mud. In some cases the nucleus fills the cavity completely, in others only in part (Fig. 21).

Other pisolites have a hard black body inside the crust which on crushing breaks into small pieces with an irregular shiny fracture. Under the microscope thin splints of these show a yellow-brown colour, as well by reflected light as by transmitted light, and they show no birefringence. They may therefore be determined as limonite (MILnER 1929).

Other pisolites have a real oolitie structure with a number of thin limonite shells within each other, the spaces between them being filled 
with a somewhat less iron-rich mud. The innermost of these spheres may either by empty or contain a semi-impregnated mud, but there is never any initial body in the form of a quartz grain or shell fragment.

Concerning the origin of lake ore, all scientists seem to agree that it comes from groundwater containing iron, which rises as springs from the lake bottom (Ånnio 1918, Naumann 1922, Aschan 1932).

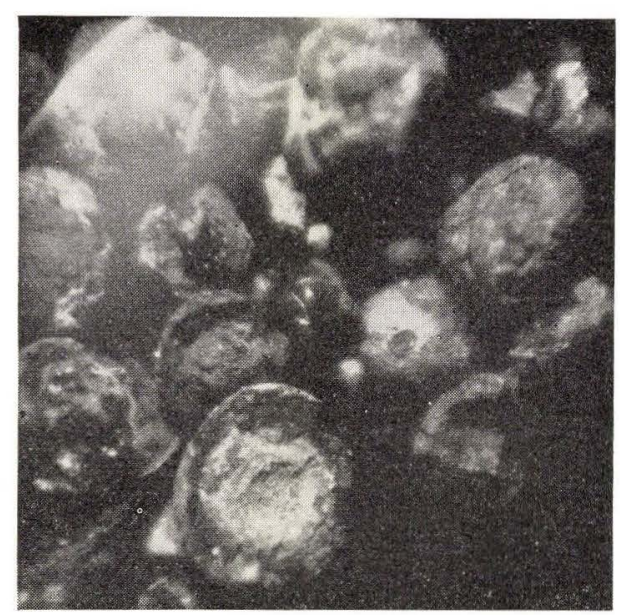

Fig. 21. Pisolite ore.

On the other hand there are very large divergencies of opinion concerning where the ore is situated on the lake bottom.

Annio states, that in Finland lake ores are mostly found in the eastern part of the country where the soil is sand and gravel, whereas they are more scarce in the western part where the soil is mostly clay.

AnNio says that ore formation demands a light penetrable soil such as sand, through which the iron bearing water may flow to the lake. He also states that lake ore must occur near a humic podsol from which the iron in the groundwater may be derived.

In order that the iron in the groundwater may not be precipitated on the way to the lake, the groundwater must contain more than 3 times as much humus as iron. The precipitation takes place on sand grains, shells, stones etc. Experiments with precipitation on different bodies gave the result that on felspar, clay and snail shells precipitation takes 6 months; on weathered granite, quartz or mica preciptation takes 4 months, and on calcite only 1 month. NaUmann states that precipitation takes place in the litoral zone where a fine ochre is formed. Iron bacteria or other iron precipitating organisms do not play any role in this process. The ochre is very soon transformed into concretions on all sorts of grains in the mud, and according to NAUMANs all ore formation takes place in this mud (Gytje). 
Thunmark (1937) states that the lake ores are mostly found on what he calls an asedimentary, minerogenic, bottom such as sand and gravel. On a sedimentary, organogenic, bottom (different types of mud, Gytje and lake ochre) the lake ore is mostly found in the shallow part, and he further writes that the lake ore is mostly situated above the upper boundary of the consolidated sediments.

There are serious reasons for protesting about the use of the terms "asedimentary bottom" and "consolidated sediments".

As far as can be seen these words originate from LUNDQUIST (1924) who speaks of the sediment limit as the boundary between gravel, sand and clay on the one side and Gytje (organogenic mud) on the other.

Gravel, sand and clay as well as gytje are, however, sedimentary rocks whereas an asedimentary bottom may only be solid rocks such as igneous rocks, gneisses, schists. The name "the sedimentary boundary" may only be used for the boundary between igneous or metamorphic rocks and sedimentary rocks, and that which LUNDQUIST calls the sedimentary boundary may better be called the Gytjeboundary (mudboundary). It is absolutely necessary that that use of the term is maintained if too many misunderstandings are not to come into existence.

Exactly the same may be said about the way THunMark uses the term "consolidated sediments". In the sedimentary petrological sense consolidated sediments are sedimentary rocks which have undergone a diagenesis ${ }^{1}$ ) and attained such a consistence that they can only be dispersed by a chemical process. Such rocks include all the clastic sediments: rocks as breccia, sandstone, shale as well as limestone. The unconsolidated sediments such as gravel, sand, clay and gytje (mud) stand in contrast to these. It is also absolutely necessary that this use of the term must be maintained if total confusion is not to result.

LUNDQUIST (1924) uses the term »consolidated« for that part of the mud which is rather hard in contrast to the uppermost semi-liquid and more mobile part, but the limit between these two parts of the mud is not definite and is very variable. In every sedimentary deposit the uppermost part will always be moving under the influence of currents and waves; this is particularly the case in very fine grained and light deposits such as organogenic muds (Gytje). Sometimes only the surface of the mud will be affected, and sometimes the deeper parts of the mud will be affected, according to the strength and nature of the forces acting, with the result that no real limit can be drawn between consolidated and unconsolidated parts in fresh sediments, which is for that matter evident from his own statements (1924).

LUNDQUIST (1942) also states that lake ore is almost never found

1) or halmyrolysis (submarine decomposition) (K. Hummel 1922.). 
on loose bottoms, because iron precipitation stops as soon as new sediments (muds) are deposited upon the concretions. LUNDQUIST's terms are here very unfortunate and unintelligible, as the term loose bottom comprises all loose sediments including sand, and further, following LUNDQUIST's own terminology, the iron ore should only be found on old, consolidated mud which is in no way the case. The terms "loose" and "hard" bottom here seem to have different meanings than in his paper of 1924, as in that paper they only contrast mud bottom with sand and gravel.

The lakes ores in lake Tystrup Sø are present under conditions indicating that much postulated by previous authors is not generally applicable. This is the case with AnNIo's assertion that lake ores are connected with sand or gravel bottom, and also LUNDQUIST's that iron precipitation stops if mud is deposited on the ore. NAUMANN's meaning that iron precipitation only takes place in the litoral zone is also wrong whereas it is quite correct that the ores are always connected with mud (gytje) deposits if here may be included calcareous mud (Kalkgytje).

It may here be stated that pisolite ores with a similar structure are also very common in clay sediments on Skallingen and other places in the marsh-lands of south-western Jutland. Here they are produced in a very stiff clay.

The production of lake ore in lake Tystrup Sø is much less than in the lakes in Småland, Sweden, probably because lake Tystrup Sø is eutropic while the Swedish lakes are oligotrophic or dystrophic.

As to the concretions, Naumany and Wesenberg Lund may be followed in their statement that shells play an essential role in the precipitation of colloidal iron; it is probably the ability of the calcium ion to coagulate colloids which is effectual.

This does not, however, explain the fact that in lake Tystrup Sø it is only the shells of Anodonta on which iron precipitates, and not, as in lake Furesø, the snails and Pisidium as well. The reason for these characteristics is sooner to be found in some other way.

In lake Furesø the iron concretions are always situated in the shell belt at depths of 10-20 m. (Wesenberg Lund 1917). This means at such depths that the shells will only to a small degree be moved by wave action and will therefore rest undisturbed in the same position for long periods. In lake Tystrup Sø the concretions are situated in depths of not more than $7 \mathrm{~m}$. The small shells will here be rolled by the waves and only the larger and heavier shells of Anodonta will lie undisturbed, and these are therefore more susceptible to iron precipitation forming crusts on the upper side. If the precipitation is caused by algae or bacteria the stationary Anodonta shells will certainly give better conditions for the growth of such organisms than the continually moving lighter shells. 
There are two astonishing things concerning the pisolite ore in the deeper parts of the lake, the presence of ferric iron (limonite) and the formation of oolites.

Twenhofel also wonders how limonite ore can be found in the hypolimnium where the oxygen content of the water is very low or completly lacking (Twenhofel 1945). He finds that a precipitation of iron carbonate would be more likely.

Oolites are still a very much discussed problem. Iron oolites are present in most of the sedimentary iron ores. Most of these are magnetite or chamosite ores, but in some, as for example in the Minette ores in Lorraine, France, limonite oolites may also be found.

These ores are certainly of marine origin, but the problem is the same as in the lake ores (ANSEL 1901). Between the oolite ore in lake Tystrup Sø and the minette ore, there is the further similarity that they are both found in strongly calcareous mud, and AREND (1932. b) attaches great importance to the fact that the oolites can only be produced in a relatively pure calcareous milieu, and that a greater admixture of quartz and clay will prevent the formation of oolites. The number of oolites always bears a close relation to the nature of the sediment.

AREND explains oolite production thus, a colloidal solution consisting of a mixture of bicarbonates and carbonates of iron and calcium, colloidal silica, aluminium and phosphate is stable as long as it is cut off from atmospheric oxygen. Iron gel is liberated at the first contact with oxygen and the oolites form by the reaction:

$$
2 \mathrm{Fe}\left(\mathrm{HCO}_{3}\right)_{2}+\mathrm{Ca}\left(\mathrm{HCO}_{3}\right)_{2}+\mathrm{O}=2 \mathrm{Fe}(\mathrm{OH})_{3}+\mathrm{CaCO}_{3}+5 \mathrm{CO}_{2}
$$

Coagulation is caused by phosphates of organic origin. In most other papers on the Minette ores great weight is laid on the phosphates as agents of oolite production. The ores contain from $0.98-3.05$ per cent $\mathrm{P}_{2} \mathrm{O}_{5}$.

Analyses of the oolites from lake Tystrup Sø and the brown Minette ore are given for comparison, the latter is from AREND (1923 a)

\begin{tabular}{|c|c|c|}
\hline & Lake Tystrup Sø & Minette ore \\
\hline $\mathrm{Fe}_{2} \mathrm{O}_{3}$ & 45.83 per cent & 68.92 per cent \\
\hline $\mathrm{P}_{2} \mathrm{O}_{5}$ & 1.33 per cent & 1.47 per cent \\
\hline
\end{tabular}

Nearly all previous authors state that oolites occur in shallow water with strong wave action. This seems necessary for oolite structure, but is also necessary to bring the contributing materials into connection with atmospheric oxygen. In lake Tystrup Sø the oolites are, however, situated at such depths that it is very doubtful if wave action reaches them, or has any influence on the quantity of oxygen in the lake bottom. 
Some measurements of the oxygen content in lake Tystrup Sø give the following results:

$\begin{array}{ccc}\text { Date } & \begin{array}{c}\text { Depth } \\ \mathrm{m}\end{array} & \begin{array}{c}\text { Oxygen } \\ \text { mg/1 }\end{array} \\ 29-4-47 & 10 & 12.4 \\ 31-5-47 & 10 & 6.88 \\ 18-8-47 & 10 & 2.26 \\ 18-8-47 & 15 & 0.97\end{array}$

The bottom mud in lake Tystrup Sø does not show any sign of strongly reducing conditions with the production of sapropel, and the quantities of oxygen are probably large enough to precipitate iron as $\mathrm{Fe}_{2} \mathrm{O}_{3}$. It seems as if the calcareous mud with its basic reaction makes the ferric iron more stable, when once precipitated in a crystalline form.

The pisolite ore in the deeper part of lake Tystrup Sø is certainly the result of a purely concretionary process influenced by lime and phosphate, and that a spheroidal shape can come in existence without any eddying of the sediment is certain from the pisolites in marsh clay. It is probably the result of colloidal processes (Lisegarg phenomena).

\section{Vivianite.}

Vivianite $\left(\mathrm{FePO}_{4}\right)$ is very common in Denmark together with peat and bog ores. It is on the whole a rather common mineral which may be formed in different ways, most frequently, however, as a precipitate in peat together with siderite, but it may also be formed by post-vulcanic processes (DoELTer 1918). It is only mentioned once from lake sediments. Wesenberg Lund (1901) states that it happened several times that he got up shells of Valvata piscinalis and Anodonta sp. which either were characterised by a deep blue colour or became such a colour after some time.

Further, stones could be covered by thick crusts of limonite with patches of the same deep blue colour. WesEnbera Lund means that this must be vivianite.

NaUmarn (1919) writes that vivianite is hitherto unknown from lake deposits. He mentions the observation made by WesexBerg LUND but is very sceptical about it. He also writes that vivianite is unknown from fossil limnic deposits, but known from marine ones. This is, however, a mistake since both peat and bog iron ore are of limnic origin.

Einsele (1938) does not know of the paper by Wesenberg Lund, but he, on the other hand, writes that vivianite may be expected to be formed in the litoral zone of lakes in connection with root tubes in the lake bottom. 
Mortimer also states that there are large quantities of phosphate in the lake bottom (Mortimer 1942).

The observation made by WESEnBERG LUND is, however, absolutely correct. In the sample 1946.2 taken opposite Suserup Woods at a depth of $8 \mathrm{~m}$ vivianite occurs as small earthy clods of light blue colour, and as blue coatings on plant remains and shell fragments. In another sample (1947.4) taken in the cross-section: Laboratory-Lindesøgaard at a depth of $5 \mathrm{~m}$, vivianite is very frequent as blue coatings on clods of the calcareous mud, shell fragments and remains of plants. It is not to be seen in the fresh sample, but only after this is sieved through the 0.5 and $0.2 \mathrm{~mm}$ sieves and dried, and then only with rather great enlargement.

Under the petrological microscope the vivianite is seen as small striated tabular crystals $30 \mu$ long and $13 \mu$ wide. The refractive index is $1.604>\gamma^{\prime}>\alpha^{\prime}>1.572$. The crystals are pleochroic with $\alpha^{\prime}$ colourless. There is no doubt that these blue coatings are vivianite.

The blue clods in the sample 1946.2 were gradually transformed into a green and yellow powder, probably by weathering to iron sulphate. Winchell (1917) states that vivianite is colourless when fresh and later becomes green, then blue and last brown.

LuNDQUisT (1936) mentions some blue-green precipitaties from the lakes Giltjaur, Volgsjön and the lakes in Ströms Vattudal, and LundQuisT further states (1924, b, p. 5) that in Rasjön in Jönköping county the colour of the sediments is very variable: white, yellow, blue, red etc. In samples from the sampling tube the uppermost part is always a thin layer of mud (Gytje) beneath which there is diatomaceous ochre. The white and blue colours are always situated in the lower part of the series and the red in the upper part. From central Norrland some yellow crystals and aggregates are mentioned from the lake Siksjön. These are stated to be iron sulphate.

The white and blue precipitates seem to be very much like the small vivianite clods found in lake Tystrup Sø. Lundquist calls them waxy; those from lake Tystrup Sø are more earthy. LuNDQUIST gives some analyses of the white sediments from Rasjön, and even if the phosphate content is low in proportion to the iron content this does not preclude their being vivianite since the quantity of phosphate is determined on the whole sediment. The only method of determining the mineralogical character of the coatings is to determine the refractive index and pleochroism under the petrological microscope.

\section{The algal encrustations.}

As mentioned before, nearly all stones along the shore of the lake are covered by crusts of calcium carbonate. The thickness of these crusts is rather variable, but rarely exceeds $2-15 \mathrm{~mm}$. The surface 


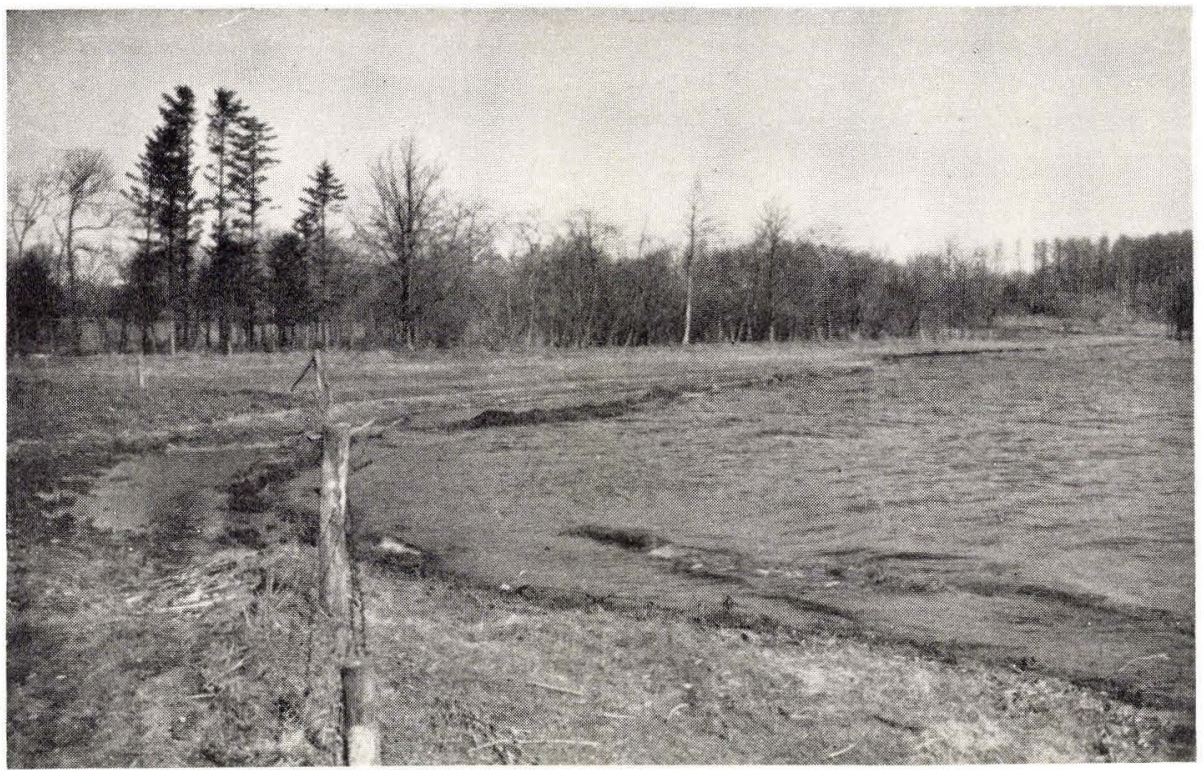

Fig. 22.

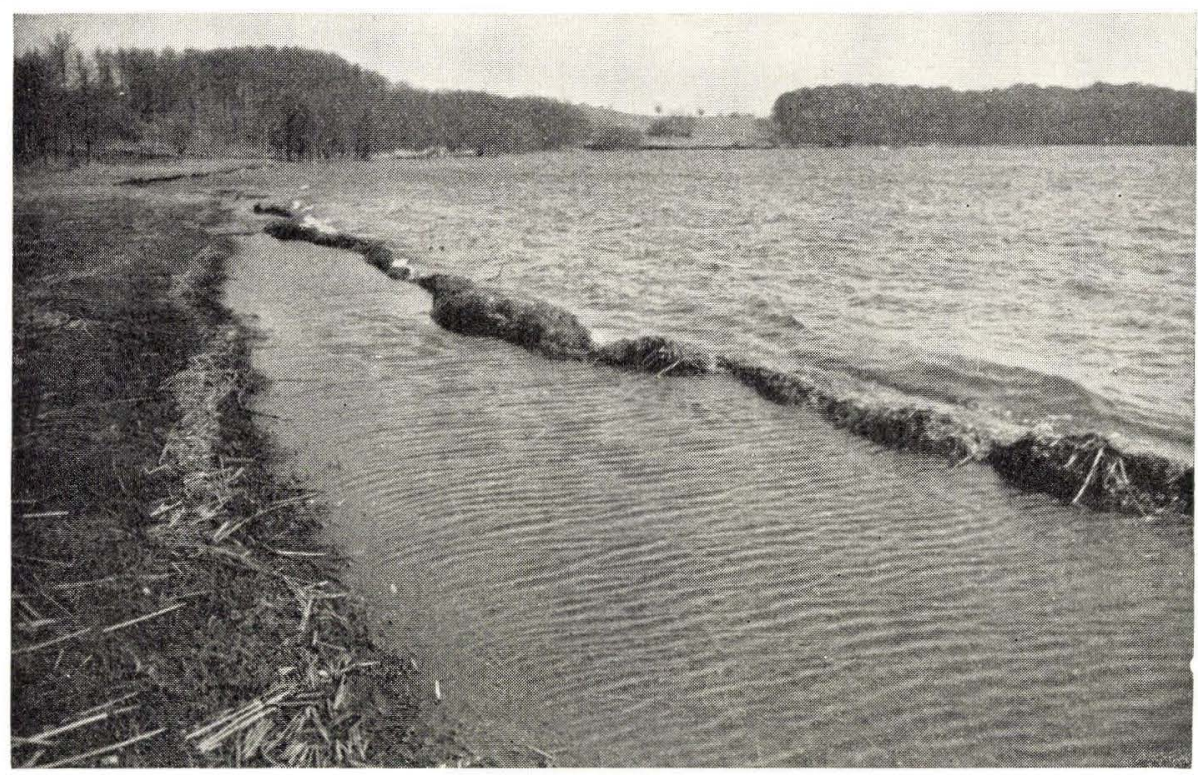

Fig. 23.

Small ridges of turf formed by ice pressure during the winter 1946 - 47. After the ice melted the lake level rose so that the ridges are some distance from the shore. 
of the encrustations is rough and uneven, and contains several small grains of sand and plant remains cemented and partly covered by calcium carbonate. Under the microscope it can be seen, that the crusts are rather loose and porous, formed by numerous small calcite crystals or aggregates of such. Each crystal has a size between 3 and $6 \mu$. Numerous diatoms are also present in the crusts. If the calcite is removed with dilute hydrochloric acid there remains a mass of algal threads. No zoned structure with yearly rings in the form of compact and loose layers, as mentioned by BAUMANN (1911), is seen in these calcite encrustations. The whole encrustation is a porous calcite mass, very easily cut with a knife.

Wesenberg Lund (1901) mentions that the stones in lake Tystrup Sø are covered by a very thin snow-white coating of diatoms in the spring, which later in the year disappears, either because it is destroyed or becomes covered by other encrustations. He further states that the calcite crusts are produced by Cyanophyceae, especially Shizothrix and Rivularia. In contrast to various other authors Wesenberg LUND states that the encrustations are most strongly developed on shores where wave action is greatest. During the investigations made in the lake in the years 1945-47 strongly developed calcite encrustations were found in places with calm water inside the dense and broad reedvegetation along the shore by the Suserup Woods.

Wesenberg Lund further states that the stones are covered in winter by a thick dark brown coating of diatoms which dissappears in April-May, and that at the same time the calcite crusts produced by the Cyanophyceae spread over the stones. These crusts increase in thickness during the summer and early autumn. In the warmest summer months when the water-level in the lake falls, many stones come to lie above the water-level and are dried by the sun. The crusts then loosen, roll up and look like lichens, whereafter they either lie among the stones or are moved by the waves. Late in the autumn they become friable and decay. These observations originate mostly from lake Furesø, but are also partly from lake Tystrup Sø.

In 1947 lake Tystrup Sø was ice covered from the middle of January to April the 14. On April the 29th., only 14 days after the ice had disappeared, all the stones on the lake bottom opposite the Suserup Woods were covered by thick, weak calcite crusts which could hardly have grown in so short a period. On the other hand, it is rather curious that these weak crusts should have lasted the whole winter without being destroyed by the ice, since in other parts of the lake, especially off Frederikskilde, the ice had pressed the turf up into long folds (figs. 22 and 23) (KAJ HANSEN 1950).

On November 14th. in the same year, the water level in the lake had fallen about $1.5 \mathrm{~m}$ as a consequence of the long, warm and dry 
summer, but all over the dry lake bottom the stones were covered with thick calcite crusts. On June 18th. 1948, the algal vegetation on the stones was seen to have grown up from the old calcite crusts which were somewhat thinner than in the autumn of 1947, but only partly destroyed.

\section{Bibliography.}

Anvio, B.: Om sjömalmerna. Geol. Komm. Finland. Geotekn. Medd., 20. Helsingfors 1918. Andersen, S. A.: Kvartærgeologiske Iagttagelser i Egnen syd for Soro. Medd. fra dansk geol. Forening Bd. 6. København 1924.

- Om Aase og Terrasser i Susaaens Vandomraade. Danmarks Geologiske Undersogelse II Række Nr. 54. Kobenhavn 1931.

Ansel, H.: Die oolitische Eisenerzformation in Deutsch Lothringen. Zeitschr. f. prakti. Geol. 9. Berlin 1901.

Arend, J. P.: La constitution des minerals oolithique et leur rapport avec le facies de couche. C. R. Acad. Science Paris 194. 1932.

- La genese des oolithe. Ibid. 1932 b

- La mode de formation de gisement oolithique en Lorrain et en Luxembourg. Ibid. 1932 c.

Ashan, O.: Om vattenhumus och des medverkan vid sjömalmernas bildning. Arkiv f. Kemi, Mineralogi och Geologi. 10 Stockh. 1932.

- Über Wasserhumus und ihre Beteiligung an der Erzbildung in den nordischen Süssgewässern. Nachr. Ges. d. Wiss. Göttingen. Math-phys. Kl. 1932.

Baumann, E.: Die Vegetation des Untersees (Bodensee). Eine floristisch kritische und biologische Studie. Archiv f. Hydrobiologie. Suppl. Bd. 1. Stuttgart 1911.

BErG, K.: Studies on the bottom animals of Esrom lake. Kgl. danske vid. Selskabs Skr. naturv. mat. Afd. 9 Række VIII. København 1938.

- Physiographical studies on the River Susaa. Folia limnologica Scandinavica. Nr. 1. København. 1944.

Bronsted, J. N. og Wesenberg Lund, C.: Chemisch physikalische Untersuchungen d. dänische Gewässer. Intern. Revue d. ges. Hydrobiologie und Hydrographie. 4. Leipzig 1912.

Deverin, L.: Les minerais de fer oolitiques des Dogger des Alpes suisses. Schweiz. Min. u. Petrogr. Mitt. Bd. 20. Zürich 1940.

Doelter, C.: Handb. d. Mineralchemie. III. 1. Dresden u. Leipzig 1918.

Einsele, W.: Ủber chemisch und kolloischemische Vorgänge in Eisen und Phosphat Systemen unter limnokemische und limnogeologische Gesichtpunkte. Archiv. f. Hydrobiologie 33. Stuttgart. 1938.

Feddersen, A.: Bidrag til de danske Indsøers Geografi. Geografisk Tidsskrift 12. København 1894.

Hansen, KaJ: The Bottom Deposits of Præstø Fiord. Folia Geographica Danica. Vol III. Tome 1. København 1945 a.

- The Middle and Upper Cambrian Sedimentary Rocks of Bornholm. Danmarks Geologiske Undersøgelse. II Række Nr. 72. København 1945 b.

- Ispresning i danske Søer. Geografisk Tidsskrift. Bd. 49. København 1950.

Hummel, K.: Die Entstehung eisenreicher Gesteine durch Halmyrolyse (= submarine Gesteinszersetzung). Geologische Rundschau. Band 13. Berlin 1922.

Johnston, J. and Williamson, E. D.: The Role of Inorganic Agencies in the Deposition of Calcium Carbonate. Journ. of Geology 24. Chicago 1916. 
Kindle, E. M.: A comparative Study of the Different Types of Thermal Stratification in Lakes and their Influence on the Formation of Marl. Ibid. 371929.

Lang, R.: Die Verwitterung, Fortschritte d. Min. Kristall, Petrogr. etc. 7. Stuttgart 1922.

Lundbeck, G.: Die Schalenzone der norddeutsche Seen. Jahrb. preus geol. Landesanstalt 49 II. Berlin 1929.

Lundquist, G. : Sedimentationstyper i Innsjöarna. Geol. För. Förh. 46. Stockholm 1924. a.

- Limnisk diatomaeeochra och des bildningsbetingelsar. Sveriges geol. Undersökning Ser. C. Nr. 320. Stockholm 1924. b.

- Utvecklingshistoriska innsjöstudier i Sydsverige. Ibid. 3301925.

- Bodenablagerungen und Entwicklungstypen d. Seen. Die Binnengewässer II. Stuttgart 1927.

- Sjösediment från mellersta Norrland. Sveriges geologiska Undersökning Ser. C. Nr. 405. Stockholm 1936 .

— Sjösediment från Bergslagen. Ibid. Nr. 4201938.

— Sjösediment och deras bildningsmillieu. Ibid. Nr. 446. 1942.

Mrkkelsen, V.: Præstø Fjord. The Development of the post-glacial Vegetation and a Contribution to the History of the Baltic. Dansk botanisk Arkiv Bd. 13. Nr. 5. København 1949.

Milner, H. B.: Sedimentary Petrography. London 1929.

Mrlthers, K.: Ledeblokke og Landsskabsformer i Danmark. Danmarks Geologiske Undersøgelse II Række Nr. 69. København 1942.

Mrtthers, V.: Beskrivelse til de geologiske Kortblade Fakse og Stevns Klint. Ibid. I Række Nr. 11. 1908.

- Grundlinier i Isens Bortsmeltning fra Sjælland. Beretning fra det 16. skandinaviske Naturforskermøde Kristiania 1916. Kristiania (Oslo) 1918.

- Det danske Istidslandskabs Terrænformer og deres Oprindelse. Danmarks Geologiske Undersøgelse III Række Nr. 28. København 1948.

Mortimer, C. H.: The Exchange of dissolved Substance between Mud and water in Lakes. Journ. of Ecology 29-30. Cambridge 1941-42.

Naumann, E.: Om järnets förekomstsätt i limniska avlagringar. Sveriges geol. Undersökning. Ser. C. Nr. 289. Stockholm 1919.

- Om roströr och vissa därmed jämförliga bildningar. Ibid. Nr. 297, 1921.

- Södra och mellersta Sveriges Sjö- och Myrmalmer. Ibid. Nr. 301, 1922.

PettiJohn, F. J.: Sedimentary Rocks. New York 1949.

PIA, J.: Die rezente Kalkgesteine. Tschermak min. u. petro. Mitt. Ergängzungsband. Leipzig 1933 a.

— Kohlensäure und Kalk. Die Binnengewässer. 13. Stuttgart 1933 b.

Richter, R.: Flachseebeobachtungen zur Paläontologie und Geologie II-IV. Senckenbergiana 4. Frankfurt a. M. 1921.

Thunmark, S.: Über die regionale Limnologie von Südschweden. Sveriges geol. Undersökning Ser. C. Nr. 410. Stockholm 1937.

Twenhofel, W. H., and others: Sediments of four Woodland lakes, Vilas County, Wisconsin. Amer. Jour. Sci. vol 242. New Haven 1944.

— and others: Sediments of Trout Lake, Wisconsin. Bull. Geol. Soc. Amer. vol. 56. Washington 1945 .

Wennberg, G.: Eisströme über Schonen während der letzten Eiszeit. Lunds Univ. Åsskrift. N. F. Avd. 2. Bd. 39. 1943.

Wesenberg Lund, C.: Studier over Søkalk, Bønnemalm og Søgytje i danske Indsøer. Medd. fra Dansk geol. Forening Nr. 7. København 1901.

- Studier over danske Indsøers Plankton. København 1904.

- Furesøstudier. Kgl. danske Vid. Selsk. Skrift. naturv. mat. Afd. 8 Række III. 1917.

Winchell, N. H. and A. N.: Elements of Optical Mineralogy. New York 1917. 


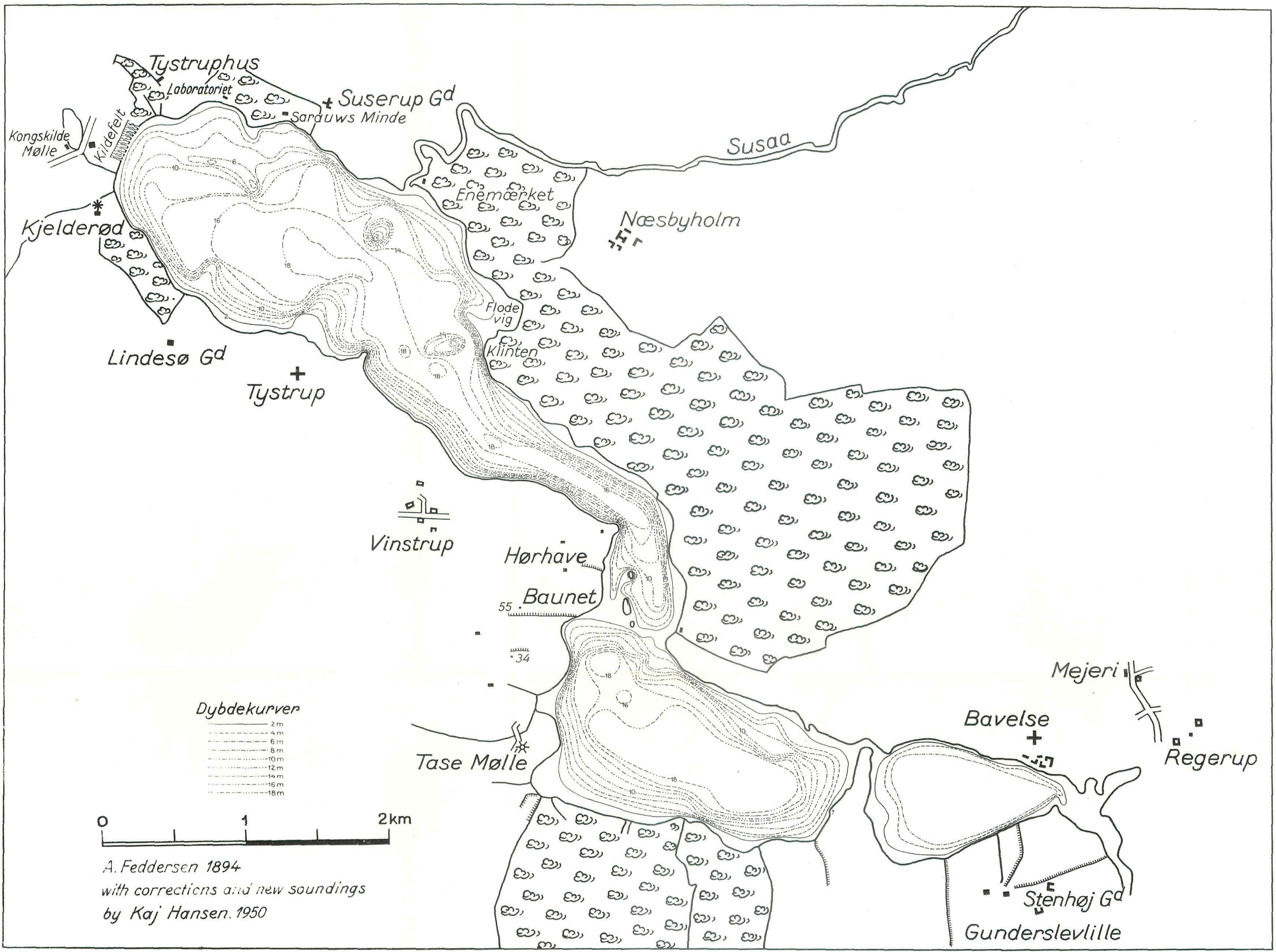

